\title{
Pharmacologically active microcarriers associated with thermosensitive hydrogel as a growth factor releasing biomimetic 3D scaffold for cardiac tissue-engineering
}

\author{
Jean-Pierre Karam ${ }^{\text {a,b,c,d }}$, Claudio Muscari ${ }^{\text {c,d }}$, Laurence Sindji ${ }^{\text {a,b }}$, Guillaume Bastiat ${ }^{\text {a,b }}$, Francesca Bonafè ${ }^{\text {c,d }}$, \\ Marie-Claire Venier-Julienne ${ }^{\mathrm{a}, \mathrm{b}}, \mathrm{N}$. Claudia Montero-Menei ${ }^{\mathrm{a}, \mathrm{b}, *}$ \\ a LUNAM Université, UMR S-1066, F-49933 Angers, France \\ b INSERM U1066, MINT “Micro et Nanomédecines Biomimétiques”, F-49933 Angers, France \\ c National Institute for Cardiovascular Research (INRC), I-40126 Bologna, Italy \\ d Department of Biomedical and Neuromotor Sciences (DIBINEM), University of Bologna, 40126 Bologna, Italy
}

\section{A R T I C L E I N F O}

\section{Article history:}

Received 3 October 2013

Accepted 25 June 2014

Available online 3 July 2014

Chemical compounds studied in this article:

Poly(DL-lactic-co-glycolic acid)

(PubChem CID: 23111554)

Glycofurol (PubMed CID: 110717)

Poloxamer 188 (PubMed CID: 24751)

Laminin (PubMed CID: 44342165)

Poly-D-lysine hydrobromide

(PubMed CID: 16219815)

Keywords:

Adipose-derived stem cells

Growth factors

Hydrogel

Pharmacologically active microcarriers

Myocardial infarction

\begin{abstract}
A B S T R A C T
The challenge of tissue engineering of the infarcted heart is how to improve stem cell engraftment, survival, homing, and differentiation for myocardial repair. We here propose to integrate human adipose-derived stem cells (ADSCs) and pharmacologically active microcarriers (PAMs), a three-dimensional (3D) carrier of cells and growth factors, into an injectable hydrogel (HG), to obtain a system that stimulates the survival and/ or differentiation of the grafted cells toward a cardiac phenotype. PAMs are biodegradable and non-cytotoxic poly(lactic-co-glycolic acid) (PLGA) microspheres conveying cells on their 3D surface that deliver continuously and in a controlled manner a growth factor (GF) acting on the transported cells and on the microenvironment to improve engraftment. The choice of the appropriate GF and its protection during the formulation process and delivery are essential. In this study two GFs, hepatocyte growth factor (HGF) and insulin-like growth factor (IGF-1), have been encapsulated under a solid state in order to limit their interaction with the polymer and conserve their integrity. GF precipitation conditions and release profile from PAMs have been first investigated before combining them to ADSCs. The released IGF-1 and HGF induced the protein synthesis of cardiac differentiation markers GATA4, Nkx2.5, cTnI and CX43 after 1 week in vitro. Moreover, the GFs accelerated cell cycle progression, as suggested by the increased expression of Cyclin D1 mRNA and the widespread distribution of Ki67 protein. Integrating PAMs within the thermosensitive P407 hydrogel increased their elastic properties but decreased the transcription of most cardiac markers. In contrast, CX43 expression increased in ADSC-PAM-GF complexes embedded within the hydrogel compared to the ADSCs cultured alone in the absence of P407. These results suggest that particulate scaffolds releasing HGF and IGF-1 may be beneficial for applications in tissue-engineering strategies for myocardial repair and the association with a P407 hydrogel can increase substrate elasticity and junction connections in ADSCs.
\end{abstract}

(c) 2014 Elsevier B.V. All rights reserved.

\section{Introduction}

Heart failure that occurs as a consequence of myocardial infarction is one of the first causes of morbidity in developed countries. Cell-based strategies have emerged as encouraging ways to achieve a suitable cardiac repair [1-3]. Beneficial effects on cardiac remodeling and left ventricular function have been obtained on animal models of myocardial infarction using adult stem cells [4-6]. These cells have been conveniently employed for cardiac regeneration therapies because of their easy accessibility and safety, large differentiating potential, ability to

\footnotetext{
* Corresponding author at: LUNAM Université d'Angers, UMR S-1066, INSERM U1066, 4 Rue Larrey, F-49933, Angers, France. Tel.: + 332446885 36; fax: + 33244684546.

E-mail address: claudia.montero-menei@univ-angers.fr (N.C. Montero-Menei).
}

secrete factors for tissue repair, and immune tolerance. However, the efficiency of stem cell transplantation is limited by several drawbacks, such as insufficient cell retention, poor survival, and early stage of differentiation. Indeed, regardless of the type of cells used, $90 \%$ of the cells die within $24 \mathrm{~h}$ after their injection in the ischemic myocardium and this is related to the slight improvement of cardiac contractility $[1,7,8]$.

Several factors play a role in determining the final amount of functional cells after their engraftment, including the ischemic environment and related inflammatory reaction [9], the scarce room to home the transplanted cells, and the transient availability of paracrine and circulating factors that can stimulate the process of cardiac repair. Indeed, several growth factors (GFs) have been demonstrated to improve myocardial regeneration by increasing survival, proliferation and differentiation of resident and transplanted cells [10-12], stimulating the 
recruitment of progenitor/stem cells [13,14], and promoting both angiogenesis and vasculogenesis $[15,16]$. Therefore, an appropriate choice of GFs and the related strategy of delivery are believed to contribute in a relevant manner to the amelioration of cell engraftment and function.

An appealing combinatorial approach for myocardium repair is the injection of drug-releasing three-dimensional (3D) scaffolds conveying stem cells. GFs that are contained in injectable gels or polymeric particles not only are more protected from the molecular changes induced by the environment but can also be released in a sustained manner stimulating muscle regeneration better than the bolus delivery of factors [17]. In addition, it has been recently reported that a combined delivery of different GFs promotes neovascularization in the ischemic tissues better than a single GF $[18,19]$. Furthermore, microspheres covered with a biomimetic surface provide additional cues stimulating the transported cell survival and differentiation [20-22]. Indeed, extracellular matrix molecules like laminin (LM) or fibronectin (FN) induce adult stem cell cardiac differentiation and survival, respectively [23,24]. Within this line, we have developed pharmacologically active microcarriers (PAMs), which combine, in an adaptable and simple device, an implantable 3D biomimetic biomaterial-based scaffold transporting cells and allowing in situ controlled and sustained drug delivery. In animal models of neuronal and cartilage disorders we have shown that these parameters promote and maintain survival, differentiation and integration of the transported cells within the host tissue after the complete degradation of the carrier $[21,22,26,27]$. These PAMs are biodegradable and biocompatible poly(lactic-co-glycolic) acid (PLGA) microspheres and are covered with molecules of the extracellular matrix [25]. However, the prolonged and complete delivery of GFs at physiological doses still remains a technological challenge for effective clinical applications. We have shown that proteins encapsulated under a nanosolid state within the PLGA polymer preserve their structure and integrity, allowing a better and prolonged release profile and the maintenance of their biological activity [28-30]. In addition, the co-precipitation of an amphiphilic polymer (poloxamer P188) with the protein further protected it from the hydrophobic environment [27-31].

In the present study we have formulated PAMs releasing the hepatocyte growth factor (HGF) or the insulin-like growth factor 1 (IGF-1), both GFs having been specifically used for bone-marrow mesenchymal stem cell commitment to the myocardial lineage [13,32,33] and cardiac repair [34-36]. The optimum conditions to obtain solid nanoparticles of these GFs were first determined with model proteins currently used in the laboratory. After their encapsulation, the protein release profile and bioactivity were studied. We then evaluated the rheological properties of a thermosensitive injectable hydrogel (HG), poloxamer 407 (P407), as a vehicle of PAMs conveying adipose-tissue derived stem cells (ADSCs), with elastic properties that may induce stem cell specification and better support the mechanical activity of the heart $[37,38]$. The release profile of a model protein from the PAMs within this gel was also evaluated. Finally, PAMs covered with LM or FN, simulating a biomimetic surface in order to improve both survival and cardiac differentiation of adult stem cells [23,24], were used to evaluate the commitment of ADSCs to cardiomyocyte lineage $[1,39]$ alone or within the hydrogel.

\section{Material and methods}

\subsection{Cell culture}

Human ADSCs have been purchased from the American type culture collection (ATTC, N. PCS-500-011). ADSCs were seeded at a density of $1 \times 10^{3}$ cells $/ \mathrm{cm}^{2}$ on $75 \mathrm{~cm}^{2}$ flasks containing Dulbecco's Modified Eagle's Medium (DMEM) supplemented with $10 \%$ fetal bovine serum (FBS), $100 \mathrm{U} / \mathrm{mL}$ penicillin, and $100 \mu \mathrm{g} / \mathrm{mL}$ streptomycin (Gibco, Invitrogen, CA, USA; normal culture medium), cultured in a humidified atmosphere of $5 \% \mathrm{CO}_{2}$ at $37{ }^{\circ} \mathrm{C}$, and allowed to reach $80 \%-90 \%$ confluence. The cells were then detached with $0.5 \mathrm{mM}$ ethylenediaminetetraacetic acid (EDTA)/0.05\% trypsin (Gibco, Invitrogen) for $5 \mathrm{~min}$ at $37{ }^{\circ} \mathrm{C}$ and replated on plastic dishes till the first or second passage, changing the medium twice a week.

\subsection{Precipitation of the protein}

Protein, glycofurol and sodium chloride were used without further purification. Experiments were carried out at $4{ }^{\circ} \mathrm{C}$. The overall mixture was prepared directly inside a centrifugation tube as follows. The protein powder was first dissolved in a non-buffered aqueous solution of sodium chloride and this solution was introduced into glycofurol. Thirty minutes later, the protein particles were recovered by centrifugation $\left(10,000 \times \mathrm{g}, 30 \mathrm{~min}, 4^{\circ} \mathrm{C}\right)$. Mixing and centrifugation times of $30 \mathrm{~min}$ were selected in order to optimize the quantity of precipitated protein.

\subsection{Experimental design for protein precipitation}

To define the optimum conditions of precipitation, an experimental design was used. Three parameters influencing protein precipitation were modified: the ionic strength, the protein concentration and the $\mathrm{pH}$. The precipitation efficiency was considered as the percentage of active protein recovered after precipitation and dissolution. The reference was the initial activity, i.e. the activity measured for the initial protein mass whose activity was $100 \%$. The protein suspensions in glycofurol were centrifuged, the supernatant was eliminated and the pellet of protein particles was dissolved in the appropriate buffer.

The measured response was the precipitation efficiency of three model proteins, lysozyme, peroxidase and human serum albumin (HSA). Nanoprecipitated lysozyme was dissolved in Tris-HCl $0.01 \mathrm{M}$ buffer, $\mathrm{pH} 7.4$, peroxidase in potassium phosphate buffer, $\mathrm{pH} 6.0$ and bovine serum albumin (BSA) in PBS, pH 7.4 as previously described [22, 29]. The two nanoprecipitated GFs, HGF and IGF-1, were dissolved in PBS, pH 7.4 and the amount of precipitated protein was readily recognized by two antibodies measured by ELISA sandwich (R \& D system, Lille, France). The biological activity of lysozyme was determined by measuring the turbidity change in a Micrococcus lysodeikticus bacterial cell suspension as previously reported $[27,30]$. The enzymatic activity of peroxidase was determined with pyrogallol as substrate.

\subsection{Protein encapsulation in PAMs}

Poly(lactic-co-glycolic acid) (PLGA)-microspheres of an average diameter of $60 \mu \mathrm{m}$ were prepared using a previously described emulsion solvent extraction-evaporation process [29]. Accurate delivery of therapeutic proteins at physiological levels requires low encapsulation loading, so according to our previous reports $[22,27,30]$ the total protein loading was $0.6 \% \mathrm{w} / \mathrm{w}$ of the amount of microspheres, i.e. $0.1 \%$ HGF, 0.1\% IGF-1 (Peprotech, Neuilly sur Seine, France), and 0.5\% HSA. First, $\mathrm{NaCl}$ and glycofurol were used to precipitate the proteins separately, as previously described [29]. For HGF and IGF-1 ( $50 \mu \mathrm{g})$, a $\mathrm{NaCl}$ solution at $0.5 \mathrm{M}$ and $2 \mathrm{M}$, respectively, was used. This solution, maintained at $4{ }^{\circ} \mathrm{C}$, was added to a poloxamer 188 excipient (poloxamer $/ \mathrm{NaCl}$ ratio $1 / 1 \mathrm{v} / \mathrm{v}$ ) in an additive to protein ratio of $20: 1$ and further mixed to glycofurol to form a $1 \mathrm{~mL}$ suspension. The same procedure was used for $250 \mu \mathrm{g}$ of $\mathrm{HSA}$ with a $\mathrm{NaCl}$ solution at $0.3 \mathrm{M}$. The nanoprecipitates were then carefully dispersed in the organic solution, water was added and the resulting $\mathrm{o} / \mathrm{w}$ emulsion formed the imprint of the microparticles, which were filtered after organic solvent extraction, as previously described [26,31]. Unloaded microparticles were prepared in the same manner without adding the protein. PLGA microspheres were either coated with FN-like sequences (FN; Sigma, Saint-Quentin Fallavier, France) or with LM combined with poly-D-lysine molecule (PDL; Sigma, France) to obtain LM-PAMs and FN-PAMs, as previously described [22,27]. Briefly, microspheres were suspended in Dulbecco's phosphate buffered saline (DPBS), sonicated until full dispersion and were then incubated with a mixture of both molecules $(9 \mu \mathrm{g} / \mathrm{mL} \mathrm{LM}$ 
and $6 \mu \mathrm{g} / \mathrm{mL}$ PDL for a final concentration of the coating molecules of $15 \mu \mathrm{g} / \mathrm{mL}$ ) by continuous stirring at $15 \mathrm{rpm}$ for $90 \mathrm{~min}$. The microspheres were formulated in aseptic conditions and were thereafter incubated for 10 min with antibiotics after the coating step. Each tube was covered with Sigmacote ${ }^{\circledR}$ (Sigma, France) to prevent product loss on the tube walls. PAMs were then freeze-dried and stored at $4{ }^{\circ} \mathrm{C}$ for the experiments or immediately used for release kinetics studies.

\subsection{Protein encapsulation efficiency}

Protein encapsulation yield was determined by measuring the entrapped proteins using ELISA kits for HGF and IGF-1 (R\&D systems, France). For the lysozyme, biological activity was measured as previously reported [26]. Briefly, protein PLGA PAMs (5 mg) were dissolved in $1 \mathrm{~mL}$ acetone in a silanized glass tube for $1 \mathrm{~h}$, the entrapped protein was separated from the dissolved polymer by centrifugation (15 $\min , 14,000 \mathrm{rpm}$ ) and the acetone was removed. To ensure that the entire polymer was dissolved and removed, the step was repeated and the pellet was resuspended in PBS. Controls performed with unloaded PAMs have no effect on the ELISA assay. Only PAMs containing a growth factor with a loading efficiency of at least $80 \%$ were considered acceptable, while formulations with lower loading efficiencies were not used.

\subsection{Characterization of functionalized surface of PAMs}

Five milligrams of PAMs was suspended in DPBS and sonicated until full dispersion of the PAMs. FN-PAMs or LM-PAMs were washed three times in sterile distilled water, lyophilized, and kept at $-20{ }^{\circ} \mathrm{C}$. The FN and LM surfaces were characterized by optical and confocal microscopy after FN and LM immunostaining. Lyophilized PAMs (1 mg) were suspended in DPBS containing 4\% BSA and 0.2\% Tween 20 (DPBSBT) and incubated for $30 \mathrm{~min}$ at room temperature under $15 \mathrm{rpm}$ stirring. Samples were then washed three times with DPBS and centrifuged (9000 $\mathrm{g}, 5 \mathrm{~min})$. Anti-FN mouse or anti-LM mouse monoclonal antibody $\left(100 \mu \mathrm{g} / \mathrm{mL}\right.$ in DPBSBT) was incubated at $37^{\circ} \mathrm{C}$ for $1.5 \mathrm{~h}$ under rotation. Samples were then washed four times before incubation with biotinylated anti-mouse IgG antibody ( $2.5 \mu \mathrm{g} / \mathrm{mL}$ in DPBS) for $1 \mathrm{~h}$, at room temperature, under rotation. After three washes, samples were incubated with streptavidin-fluoroprobe 547 (1:500 in DPBS) at room temperature, for $40 \mathrm{~min}$, under rotation. Samples were observed under optical microscopy (Axioskop, Carl Zeiss, LePecq, France) and confocal microscopy (Olympus FluoviewTM TU 300, Rungis, France). Three independent experiments were performed and every condition was observed in triplicate.

\subsection{Release kinetics, in vitro study}

The in vitro release profile of protein from PAMs was determined from $\mathrm{n}=3$ experiments by adding $250 \mu \mathrm{L}$ of PBS buffer, $\mathrm{pH} 7.4$, containing $1 \% \mathrm{w} / \mathrm{v}$ BSA to $2.5 \mathrm{mg}$ of microspheres into Eppendorf tubes. The tubes were closed and incubated in a shaking water bath $\left(37^{\circ} \mathrm{C}\right.$, $125 \mathrm{rpm}$ ). At different times, the tubes were centrifuged for $5 \mathrm{~min}$ at $3000 \mathrm{rpm}$ and $250 \mu \mathrm{L}$ of the supernatant was collected for analysis and replaced by fresh buffer. The percentage of released GF was evaluated by ELISA (R\&D systems, France). The ratio of cumulative release (in percent) was calculated based on the total amount of protein obtained from the encapsulation yield. Then, the GFs that were released from PAMs at different time-points were checked for their bioactivity by performing a proliferation assay (Alamar Blue assay) with an appropriate cell type (HUVECs for HGF and NIH3T3 fibroblasts for IGF-1). Their effects on cell expansion were compared to the stimulation exerted by the corresponding native, non encapsulated, standard GFs. Since this response is concentration dependent, we first tested different concentrations of each native GF in order to obtain the best dose that most appropriately stimulated cell proliferation. Indeed, very high concentrations as well as too low concentrations may be either toxic or may not induce any cell response. Hence, we first collected each aliquot at each time-point of the release kinetics assay and measured the concentrations of the GF released from PAMs by ELISA. Then, each aliquot at a known GF concentration was diluted to the same GF concentration that had provided the best cell proliferating response obtained with the standard GF. Finally, each of these normalized aliquots (all with the same concentration of GF) was used to stimulate the proliferation of HUVECs, for HGF, and NIH3T3 fibroblasts, for IGF-1. At the end of the proliferation assay the amount of expanded cells was measured and expressed as percentage of the number of cells grown in the presence of the same concentration of the standard GF. For both HGF and IGF-1, we obtained values of bioactivity ranging from $90 \%$ to $100 \%$.

\subsection{Hydrogel preparation and rheology}

Poloxamer 407 (P407, pluronic F127) HG was prepared by dissolving P407 (Sigma Aldrich, St. Louis, MO) in phosphate buffered saline (PBS) ( $\mathrm{pH} 7.4)$ at $4{ }^{\circ} \mathrm{C}$ under sterile conditions. Once completely dissolved at low temperature, $\mathrm{P} 407$ formed a clear solution which turned into a transparent gel when brought up to room temperature or $37^{\circ} \mathrm{C}$. To obtain PAM-loaded HG, PAMs were dispersed in P407 solution at $4{ }^{\circ} \mathrm{C}$, at $1 \% w / v$ concentration and in vivo injection concentration, corresponding to $10 \% w / v$, before the gel formation increasing temperature. The viscoelastic properties of three HG concentrations (18\%,20\%, and $22 \% w / v)$, with or without dispersed PAMs, were investigated with a Kinexus ${ }^{\circledR}$ rheometer (Malvern S.A., Worcestershire, UK), used with plate-plate geometry (20 mm-diameter) with an $800 \mu \mathrm{m}$ gap.

The HG rheological properties were evaluated in triplicate as follows:

Strain sweep experiments: Frequency was fixed at $1 \mathrm{~Hz}$ and elastic $\left(\mathrm{G}^{\prime}\right)$ and viscous $\left(\mathrm{G}^{\prime \prime}\right)$ moduli were determined $v s$. strain variation from 0.01 to $100 \%$. Experiments were performed at $37^{\circ} \mathrm{C}$.

Frequency sweep experiments: Strain was fixed at $0.1 \%$ and elastic $\left(G^{\prime}\right)$ and viscous $\left(\mathrm{G}^{\prime \prime}\right)$ moduli were determined $v s$. frequency variation from 0.01 to $100 \mathrm{~Hz}$. Experiments were performed at $37^{\circ} \mathrm{C}$.

Temperature ramp experiments: Elastic $\left(\mathrm{G}^{\prime}\right)$ and viscous $\left(\mathrm{G}^{\prime \prime}\right)$ moduli were determined $v$ s. temperature cycles from $37^{\circ} \mathrm{C}$ to $4{ }^{\circ} \mathrm{C}$ and from $4{ }^{\circ} \mathrm{C}$ to $37^{\circ} \mathrm{C}$. Strain and frequency were fixed at $0.1 \%$ and $1 \mathrm{~Hz}$, respectively.

\subsection{Protein release profile from PAMs within the hydrogels}

PAMs releasing lysozyme were formulated as described by Giteau A. et al. [29] and were then coated with extracellular matrix proteins. One percent $w / v$ of PAMs were then added within the HG at the three established concentrations. The tubes were closed and incubated in a shaking water bath $\left(37^{\circ} \mathrm{C}, 125 \mathrm{rpm}\right)$ and, at interval times, were centrifuged for $5 \mathrm{~min}$ at $3000 \mathrm{rpm}$. The supernatants were collected for analysis and replaced by fresh buffer. The biological activity of lysozyme released was determined by measuring the turbidity change in a M. lysodeikticus bacterial cell suspension as reported above [29].

\subsection{Cell number and differentiation in 3D culture conditions}

For 3D cell studies, culture-expanded ADSCs were harvested and cultured with FN- or LM-coated PAMs for cell quantification and compared to 2D cell culture (standard plates). LM coated PAMs were used for cell differentiation. Three independent experiments were performed.

HG was synthesized in the characterized stiffness range of $18-22 \%$ total polymer content. We prepared $18 \%, 20 \%$ and $22 \%$ HG by dissolving sterile poloxamer 407 (P407; Sigma Aldrich, St. Louis, MO) in DMEM supplemented with $10 \% \mathrm{FBS}, 100 \mathrm{U} / \mathrm{mL}$ penicillin, and $100 \mu \mathrm{g} / \mathrm{mL}$ streptomycin (Gibco, Invitrogen, CA, USA; normal culture medium) at $4{ }^{\circ} \mathrm{C}$. 
For quantification studies, ADSCs were suspended within the HGs with and without PAMs at a concentration of $0.5 \times 10^{6}$ cells $/ \mathrm{cm}^{3}$ into an ultra-low attachment microplate. Prior PAM-cell complex incorporation within the HGs, an adhesion step incubating cells with PAMs for $4 \mathrm{~h}$ was necessary. These cell-loaded HGs were then incubated at $37{ }^{\circ} \mathrm{C}$ in $5 \% \mathrm{CO}_{2}$ for 5 days and HGs were removed at $1,2,3$ and 5 days. HG samples were then assayed for cell number using the Cyquant Cell Proliferation assay (Molecular Probes, Eugene, OR) against generated cell number standards.

For differentiation studies only the $22 \% \mathrm{P} 407$ was prepared. ADSCs were then cultured with a mixture of equal amounts of LM-PAMs releasing HGF and LM-PAMs releasing IGF-1 (PAM-GFs) with and without the HG. Briefly, $0.5 \mathrm{mg}$ of LM-PAM-HGF and $0.5 \mathrm{mg}$ LM-PAM-IGF-1 were first incubated for $4 \mathrm{~h}$ with $4 \times 10^{5}$ ADSCs without any agitation in a 24-well ultra low attachment plate (Costar) in DMEM supplemented with $3 \%$ FBS. Once adhered, PAM-cell complexes were added within the 22\% P407. Cardiomyogenic commitment of ADSCs adhered to PAM-GFs with and without HG was assessed by qRT-PCR and immuno-cytochemistry.

\subsection{Cardiac primer design and validation}

A panel of cardiac genes, the transcription factors GATA binding protein 4 (GATA4), myocyte enhancer factor 2C (MEF2C), and NK2 homeobox 5 (Nkx2.5), the sarcomeric ATPase, $\mathrm{Ca}^{2+}$ transporting, cardiac muscle, slow twitch 2, variant a (SERCA2a), the cardiac myosin light chain 2 (MLC-2V), the cardiac troponin I (cTnI), the gap junction protein alpha 1, connexin 43 (CX43/GJA1), and Cyclin D1 have been used to study ADSC mRNA levels during commitment (Table 1).

To ascertain whether ADSCs were committed toward cells other than cardiomyocytes, we also investigated specific transcripts that have been approved in the literature as markers of chondrocytes (Col2a1/collagen type II-alfa1), osteoblasts (BGLAP-osteocalcin), adipocytes (FABP4/fatty acid binding protein 4), endothelial cells (PECAM1/ CD31), and neurons (TUBB3/tubulin beta 3-class III) (Table 1).

The following experimental details were performed following the guidelines of the SCCAN core facility (Service Commun de Cytométrie et d'Analyse Nucléotidique, Angers, France). Human sequences were determined using PubMed nucleotide search (www.ncbi.nlm.nih.gov) and Ensembl (www.ensembl.org) websites. The online freeware Primer blast (http://www.ncbi.nlm.nih.gov/tools/primer-blast/) was used for primer modeling, ClustalW (www.ebi.ac.uk) to align nucleotidic sequences, and nucleotide blast (www.ncbi.nlm.nih.gov) to confirm the specificity of the defined primer sequences. When possible, pairs of primers were designed across intron-spanning regions to avoid genomic DNA contamination. Sense and antisense desalted primer pairs (Eurogentec, Angers, France) were mixed in RNAse free water at a final concentration of $5 \mathrm{mM}$ and validated using cDNA from human adult or fetal heart and commercial quantitative polymerase chain reaction (PCR) Human Reference cDNA (Clontech, Takarabio, SaintGermain-en-Laye, France). The melting peak of the amplicon had to be narrow and unique, and its size and specificity were confirmed by electrophoresis. Finally, a serial dilution of the PCR product was reamplified to draw a linear curve $\mathrm{Ct}=\mathrm{f}$ (quantity). The efficiency of the primer was calculated from the slope of the linear curve: $\mathrm{E}=$ $\left[10^{(-1 / \text { slope })}-1\right] \times 100$. Only primer pairs with efficiency greater than $80 \%$ were validated for use (Table 1 ).

\subsection{Quantitative real-time PCR ( $q R T-P C R$ )}

ADSCs were washed in DPBS. Following the manufacturer's guidelines, cells were lysed in a $1 \% \beta$-mercaptoethanol containing buffer and RNA was extracted following a treatment by DNAse to remove any traces of genomic DNA (Total RNA isolation Nucleospins ${ }^{\circledR}$ RNA II, Macherey Nagel, Hoerdt, France). First strand cDNA synthesis was performed with a Ready-To-Go You-Prime First-Strand Beads ${ }^{\circledR}$ kit in combination with random hexamers (Amersham Biosciences, Orsay, France) using $1 \mu \mathrm{g}$ RNA according to the manufacturer's guidelines. Following first-strand cDNA synthesis, cDNAs were purified (Qiaquick PCR purification kit, Qiagen, Courtaboeuf, France) and eluted in $50 \mu \mathrm{L}$ RNAse free water (Gibco). Five microliters of cDNA (1:20) was mixed with iQ SYBR Green Supermix (Biorad) and primer mix $(0.2 \mathrm{mM})$ in a final volume of $15 \mu \mathrm{L}$. Amplification was carried out on a Chromo4 thermocycler (Biorad) with a first denaturation step at $95^{\circ} \mathrm{C}$ for $3 \mathrm{~min}$ and 40 cycles of $95{ }^{\circ} \mathrm{C}$ for $10 \mathrm{~s}, 55^{\circ} \mathrm{C}$ for $15 \mathrm{~s}$ and $72{ }^{\circ} \mathrm{C}$ for $15 \mathrm{~s}$. After amplification, a melting curve of the products

Table 1

Human specific cardiac primers.

\begin{tabular}{|c|c|c|c|}
\hline Gene & Full name & NM accession number & Sequences \\
\hline GATA4 & GATA binding protein 4 & NM_002052.3 & $\begin{array}{l}\text { Fwd: AGATGCGTCCCATCAAGACG } \\
\text { Rev: GGAGCTGGTCTGTGGAGACT }\end{array}$ \\
\hline MEF2C & Myocyte enhancer factor $2 \mathrm{C}$ & NM_001131005.2 & $\begin{array}{l}\text { Fwd: CTAATCTGATCGGGTCTTCCTTCAT } \\
\text { Rev: TTTTTCTCCCCATAGTCCCCG }\end{array}$ \\
\hline Nkx2.5 & NK2 homeobox 5 & NM_004387.3 & $\begin{array}{l}\text { Fwd: CTATCCACGTGCCTACAGCG } \\
\text { Rev: GCCGCTCCAGTTCATAGACC }\end{array}$ \\
\hline SERCA2a & ATPase, $\mathrm{Ca}^{2+}$ transporting, cardiac muscle, slow twitch $2($ ATP2A2) variant a & NM_001681.3 & $\begin{array}{l}\text { Fwd: ACCTGGAACCTGCAATACTGG } \\
\text { Rev: TGCACAGGGTTGGTAGATGTG }\end{array}$ \\
\hline MLC-2V & Myosin light chain 2, cardiac, slow & NM_000432.3 & $\begin{array}{l}\text { Fwd: GATGGAGCCAATTCCAACGTG } \\
\text { Rev: ACGTTCACACGCCCAAGAG }\end{array}$ \\
\hline cTnI & Troponin I type 3 (cardiac) & NM_000363.4 & $\begin{array}{l}\text { Fwd CCTGCGGAGAGTGAGGATCT } \\
\text { Rev: CAGTGCATCGATGTTCTTGCG }\end{array}$ \\
\hline CX43 & Gap junction protein alpha $1,43 \mathrm{kDa}$ & NM_000165.3 & $\begin{array}{l}\text { Fwd: TCTGAGTGCCTGAACTTGCC } \\
\text { Rev: CACCTTCCCTCCAGCAGTTG }\end{array}$ \\
\hline Cyclin D1 & G1/S-specific Cyclin-D1 & NM_053056 & $\begin{array}{l}\text { Fwd: GGACAGGAAGTTGTTGGGC } \\
\text { Rev: TCTCTCCTAATATGCCAGAGG }\end{array}$ \\
\hline Col2a1 & Collagen type II alpha 1 & NM_033150 & $\begin{array}{l}\text { Fwd: GAGGGGATCGTGGTGACAAAGG } \\
\text { Rev: TTGCATTACTCCCAACTGGGCG }\end{array}$ \\
\hline BGLAP & Osteocalcin & NM_199173 & $\begin{array}{l}\text { Fwd: GGCGCTACCTGTATCAATGG } \\
\text { Rev: TCAGCCAACTCGTCACAGTC }\end{array}$ \\
\hline FABP4 & Fatty acid binding protein 4 & NM_001442 & $\begin{array}{l}\text { Fwd: ACAGCACCCTCCTGAAAACTGC } \\
\text { Rev: TGTTAGGTTTGGCCATGCCAGC }\end{array}$ \\
\hline PECAM1 & CD31 & NM_000442 & $\begin{array}{l}\text { Fwd: ACAGTGGGACGTATATCTGC } \\
\text { Rev: GGACTTCGATGGTCTGTCC }\end{array}$ \\
\hline TUBB3 & Tubulin beta 3 class III & NM_006086 & $\begin{array}{l}\text { Fwd: CCAGTATGAGGGAGATCG } \\
\text { Rev: CACGTACTTGTGAGAAGAGG }\end{array}$ \\
\hline
\end{tabular}


determined the specificity of the primers for the targeted genes. A mean cycle threshold value $(\mathrm{Ct})$ was obtained from at least two measurements for each cDNA. Several reference genes, glyceraldehyde-3phosphate dehydrogenase (GAPDH, NM_002046), hypoxanthine phosphoribosyltransferase 1 (HPRT1, NM_000194), B-actin (Actb, NM_ 001101), 30S ribosomal protein S18 (Rps18, NM_001093779) and heat shock $90 \mathrm{kDa}$ protein $1 \beta$ (Hspcb, NM_007355) were tested and the three best ones, those that are stable during the differentiation process, were chosen for normalization using the GeNorm software described previously [39]. The relative transcript quantity (Q) was determined by the $\Delta \mathrm{cT}$ method $\mathrm{Q}=\mathrm{E}^{\text {(Ct min in all the samples tested }-\mathrm{Ct} \text { of the sample) }}$, where $\mathrm{E}$ is related to the primer efficiency ( $\mathrm{E}=2$ if the primer efficiency $=100 \%$ ). Relative quantities $(Q)$ were normalized using the multiple normalization method with the geometric mean of the relative transcript quantity $(\mathrm{Q})$ of the three best reference genes as described in Vandesompele et al. [40].

\subsection{Immunofluorescence}

ADSCs adhered on empty PAMs or LM-PAMs releasing GFs were used for GATA4, Nkx2.5, MEF2C, cTnI and CX43 immunocytofluorescence. Briefly, PAM/cell complexes were transferred into a $1.5 \mathrm{~mL}$ tube and washed three times with DPBS, and the PAM/cell complexes were fixed with $4 \%$ paraformaldehyde at $4{ }^{\circ} \mathrm{C}$ for $15 \mathrm{~min}$ and then permeabilized with $0.2 \%$ TritonX 100 (Sigma) for 5 min. They were then blocked with DPBS, $10 \%$ normal goat serum (Sigma) and $4 \%$ BSA at room temperature for $45 \mathrm{~min}$. After washing, PAM/cell complexes were incubated overnight at $4{ }^{\circ} \mathrm{C}$ with goat anti-GATA4 (1:100, Abcam, Paris France), mouse anti$\operatorname{Nkx2.5}$ (1:200, Abcam), mouse anti-cTnI (1:100, Abcam), rabbit antiMEF2C (1:100, Abcam) and rabbit anti-CX43/GJA1 (1:100) in DPBS, 4\% BSA and $0.2 \%$ TritonX-100. Isotypic controls were made with IgG1k (BD Biosciences, Rungis, France) and IgG2bk (BD Biosciences). After rinsing, the PAM/cell complexes were incubated with the corresponding secondary biotinylated anti-mouse or anti-goat or anti-rabbit antibody (1:200, Eurobio, Courtaboeuf, France) in DPBS, 4\% BSA, and $0.2 \%$ TritonX-100 for $1 \mathrm{~h}$. Finally, after rinsing again and following incubation with streptavidin-FITC (1:500, Dako, Trappes, France) or streptavidinrhodamine (1:500, Dako) in DPBS for $40 \mathrm{~min}$, a 2 min centrifugation at $1000 \mathrm{rpm}$ was done to remove the supernatant. The PAM/cell complexes were mounted on slides (Mounting Media, Dako) and observed with a fluorescence microscope (Axioskop, Carl Zeiss, LePecq, France).

\subsection{Statistical analysis}

Data were expressed as mean $\pm \mathrm{SD}$. The values were analyzed using one-way ANOVA and Tukey multiple comparison test as post-ANOVA test. Differences were considered significant for $\mathrm{p}<0.05$.

\section{Results}

\subsection{Protein precipitation conditions}

An excess of water-miscible organic solvent, glycofurol, and sodium chloride was conjunctively added to protein solutions to induce the formation of fine protein particles. As the efficiency of precipitation varies with the process conditions, the composition of the medium was varied in a defined experimental domain at $4{ }^{\circ} \mathrm{C}$ and in an excess glycofurol set at $1.04 \mathrm{~g} / \mathrm{mL}$. The $\mathrm{pH}$ of the protein solution showing the best protein precipitation efficiency corresponds to the isoelectric point of the protein, so for each experiment the $\mathrm{pH}$ of the medium was adjusted to the isoelectric point of the considered protein. Peroxidase and HSA showing different molecular weights and isoelectric points were used as model proteins (Table 2, Fig. 1). These physicochemical parameters have been shown to influence protein precipitation as described by Giteau et al. [29,31]. Precipitation optima corresponded to the recovery of more than $90 \%$ of the initial protein mass in its biologically active state. For peroxidase, salt-induced ionic strength of $0.01 \mathrm{M}$ permitted to obtain a precipitation efficiency of $100.1 \pm 9.8 \%$ while for HSA at $0.5 \mathrm{M}$ the precipitation efficiency was $100.4 \pm 7.1 \%$ (Table 2). We found that the protein concentration also greatly influenced protein precipitation and should be taken into consideration. Combined analysis of these results underlines that protein precipitation optima correspond to higher protein concentrations (at least at $5.5 \mathrm{mg} / \mathrm{mL}$ ) (Fig. 1).

We could precipitate $50 \mu \mathrm{g}$ of HGF in a solution of $0.5 \mathrm{M} \mathrm{NaCl}$ at the final concentration of $5.5 \mathrm{mg} / \mathrm{mL}$, with an output of precipitation of $90.0 \pm 10.3 \%$ of the initial HGF determined by an ELISA (Table 2). For IGF-1 with a very low molecular weight we applied a screening method placing the $\mathrm{pH}$ equal to the isoelectric point and varying the protein concentration and ionic strength. We could precipitate $10 \mu \mathrm{g}$ of IGF- 1 in a solution of $2 \mathrm{M} \mathrm{NaCl}$ at the final concentration of $5.5 \mathrm{mg} / \mathrm{mL}$ with $1.04 \mathrm{~g}$ glycofurol (Table 2). Under these conditions, $81.3 \pm 20 \%$ of the initial IGF-1 could be precipitated. Lysozyme, the current model protein used in the laboratory $[27,29]$, was precipitated at $0.3 \mathrm{M} \mathrm{NaCl}$, with a protein concentration of $5.5 \mathrm{mg} / \mathrm{mL}$ (Table 2).

\subsection{PAM characterization and GF release profile}

Microspheres with a bell-shaped size distribution (mean diameter $=$ $62 \pm 5 \mu \mathrm{m}$ ) were obtained for all the formulations performed (Fig. 2A). After coating the microspheres, an immunofluorescence study showed a homogeneous distribution of LM on the surface of the PAMs (Fig. 2B). The encapsulation yield of HGF and IGF- 1 was $95 \pm 13 \%$ and $99 \pm 4 \%$, respectively.

A continuous HGF release profile from PAMs was observed for at least 3 weeks consisting in a cumulative release of $1204 \mathrm{ng} / \mathrm{mL}$ and representing $24 \%$ of the entrapped protein (Fig. 2C, black line). The HGF collected from each sample of the release kinetics assay was able to stimulate HUVEC proliferation as well as the standard HGF (Fig. 2C, red line). Indeed, the cumulative release profile of the bioactive HGF overlapped over time the curve of HGF measured by ELISA. Finally, the IGF-1 release profile from PAMs was quantified in vitro by ELISA and showed a $32 \%$ protein release after 3 weeks, representing $1565 \mathrm{ng} / \mathrm{mL}$ (Fig. 2D, black line). The IGF-1 collected from each sample of the release kinetics assay was able to stimulate NIH3T3 proliferation similar to the standard IGF-1 (Fig. 2D, red line).

\subsection{Pluronic F127/poloxamer 407 hydrogel characterization}

The viscoelastic moduli ( $G^{\prime}$ : elastic modulus and $G^{\prime \prime}$ : viscous modulus) of P407 increased with the concentration of P407 (Table 3A).

Table 2

Recapitulative table of protein characteristics and precipitation conditions.

\begin{tabular}{|c|c|c|c|c|c|}
\hline & Mw (kDa) & Isoelectric point & $\mathrm{NaCl}$ concentration $(\mathrm{M})$ & Protein concentration $(\mathrm{mg} / \mathrm{mL})$ & Precipitation efficiency (\%) \\
\hline Lysozyme & 14 & 11 & $0.3 \mathrm{M}$ & 5.5 & $83.3 \pm 14.6$ \\
\hline Peroxidase & 40 & 7.2 & $0.01 \mathrm{M}$ & 5.5 & $100.1 \pm 9.8$ \\
\hline HSA & 66.7 & 4.7 & $0.5 \mathrm{M}$ & 5.5 & $100.4 \pm 7.1$ \\
\hline HGF & 80 & 7.8 & $0.5 \mathrm{M}$ & 5.5 & $90.0 \pm 10.3$ \\
\hline IGF-1 & 7.6 & 7.8 & $2 \mathrm{M}$ & 5.5 & $81.3 \pm 20$ \\
\hline
\end{tabular}



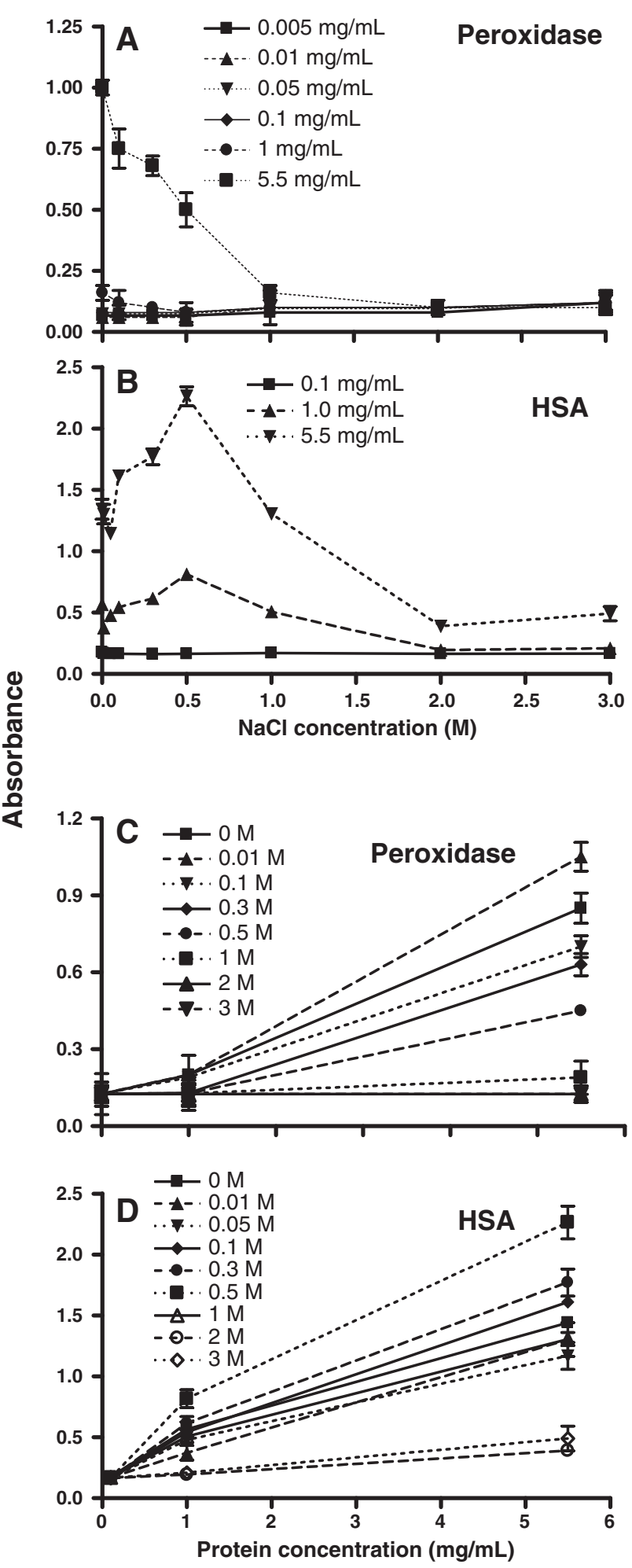

Fig. 1. Protein precipitation conditions. Peroxidase and HSA were used as model proteins to predict the precipitation environment of GFs. Two parameters were modified to induce protein precipitation, ionic strength and protein concentration, while the $\mathrm{pH}$ value was fixed to the isoelectric point of the considered protein. The precipitation of peroxidase and $\mathrm{HSA}$ occurred at $0.01 \mathrm{M} \mathrm{NaCl}$ and $0.5 \mathrm{M} \mathrm{NaCl}$, respectively, at a protein concentration of $5.5 \mathrm{mg} / \mathrm{mL}$ for both proteins (A, B). The precipitation of peroxidase and HSA was dependent on protein concentration (C, D). Values are expressed as mean \pm SD of absorbance units.

$\mathrm{G}^{\prime}$ values were about $2 \mathrm{kPa}, 8 \mathrm{kPa}$, and $10 \mathrm{kPa}$ and $\mathrm{G}^{\prime \prime}$ values were about $1 \mathrm{kPa}, 2 \mathrm{kPa}$, and $3 \mathrm{kPa}$ for 18\%, 20\%, and 22\% ( $\left.w / v_{\text {water }}\right)$ P407 gels, respectively. Interestingly, addition of PAMs into the gels modified their viscoelastic properties compared to the gel without PAMs and the variations depended on the P407 concentration. With 18\% (w/vater $)$ P407 gel, $\mathrm{G}^{\prime}$ value was strongly increased (about $9 \mathrm{kPa}$ ) with the addition of $1 \%\left(w / w_{\text {polymer }}\right)$ of PAMs and the addition of higher PAM amount $\left(10 \% \mathrm{w} / w_{\text {polymer }}\right)$ seemed to produce a smoother gel $\left(\mathrm{G}^{\prime}\right.$ value at about $4 \mathrm{kPa}$ ) but harder than the gel without PAMs. The increase of $\mathrm{G}^{\prime}$ with the addition of PAMs was not so distinct with higher P407 gel concentrations: $\mathrm{G}^{\prime}=10 \mathrm{kPa}$ with the addition of $1 \%\left(w / w_{\text {polymer }}\right)$ of PAMs with $20 \%$ $\left(w / v_{\text {water }}\right)$ P407 gel, and $\mathrm{G}^{\prime}=12$ and $15 \mathrm{kPa}$ with the addition of 1 and $10 \%\left(w / w_{\text {polymer }}\right)$ of PAMs, respectively, with $22 \%\left(w / v_{\text {water }}\right)$ P407 gel.

On the other hand, the elasticity of the gels, illustrated by the ratio $G^{\prime} / G^{\prime \prime}$, was increased by the addition of PAMs whatever the concentration of P407. While the mean of this ratio was about 3.6 for the gel without PAMs, it increased to 18.7 (mean value) with the addition of $1 \%\left(w / w_{\text {polymer }}\right)$ of PAMs. Addition of higher amount of PAMs $\left(10 \% w / w_{\text {polymer }}\right)$ decreased the elasticity of the $18 \%\left(w / v_{\text {water }}\right)$ P407 gel, making the gel smoother in a similar way to the decrease of $\mathrm{G}^{\prime}$, while the elasticity of the $22 \%\left(w / v_{\text {water }}\right)$ P407 gel remained at 13.5 (ratio $\mathrm{G}^{\prime} / \mathrm{G}^{\prime \prime}$ ).

The transition temperatures $\left(\mathrm{T}_{\mathrm{G}-\mathrm{S}}\right.$ : gel-solution and $\mathrm{T}_{\mathrm{S}-\mathrm{G}}$ : solutiongel) were not impacted by the addition of PAMs (Table 3B). Whatever the amount of PAMs added (between $0 \%$ and $10 \%\left(w / w_{\text {polymer }}\right)$ ) and whatever the P407 gel concentrations (from $18 \%$ to $22 \% w / v_{\text {water }}$ ), $\mathrm{T}_{\mathrm{G}-\mathrm{S}}$ and $\mathrm{T}_{\mathrm{S}-\mathrm{G}}$ were comprised in $6{ }^{\circ} \mathrm{C}$ and $10{ }^{\circ} \mathrm{C}$ intervals, respectively. The variations of temperature transitions were not correlated with P407 gel concentration or amount of added PAMs.

\subsection{PAM protein release profile within the HGs}

The effect of P407 concentration (18\%, 20\%, 22\%) on the model protein lysozyme released from PAMs at $37^{\circ} \mathrm{C}$ is shown in Table $3 \mathrm{C}$. It is apparent that the protein release rate decreases as the $\mathrm{P} 407$ concentration increases. Increasing the concentration of P407 from $18 \%$ to $22 \%(w / v)$ decreased the cumulative percent drug released. After 3 weeks, the percentage of lysozyme released was $12 \%$ and $9 \%$ within the $18 \%$ and $22 \%$ HG, respectively, compared to the $33 \%$ of lysozyme released from PAMs in control buffer. This phenomenon is due to an increase in chain entanglement and gel formation that favors hydrophobic interactions. This entanglement is also more marked at higher concentrations of P407, yielding an increase in gel strength and consequently a decrease of the drug release rate.

\subsection{Behavior within P407 of ADSCS adhered onto PAMs}

We then tested whether the P407 hydrogel could be cytotoxic for ADSCs. Compared to the number of cells cultured in a 2D condition (on culture plates), the cells cultured in suspension decreased in numbers at day 1 or day 3 , as no anchorage was provided for their support. The HG did not provide a good anchorage for the cells as a similar decrease in cell numbers (50\%) was observed at day 1 . However, the HG is not cytotoxic for the cells as no difference in cell number was observed at 3 days in culture between the number of cells cultured within the P407 HG and that in the 2D conditions (Fig. 3A). These results confirm the need for a 3D support provided by the gel to stimulate cell proliferation. In contrast with cells seeded on polystyrene dishes, the cells did not spread but retained a round shape. To provide a 3D structure to the cells, we cultured ADSCs on PAMs for 3 days and analyzed the interactions of ADSCs adhered onto PAMs within the $18 \%$ and $22 \%$ HGs. When the ADSCs adhered onto PAMs were mixed within the gels the percentage of living cells did not significantly change regardless of the LM- or FN-coating that was utilized (Fig. 3B). Altogether, these results show that the HG is not cytotoxic for the human ADSCs. However, in all conditions tested the number of cells was within the range of $50-60 \%$ of cells when compared to the $2 \mathrm{D}$ condition. Nevertheless, it should be noted that $2 \mathrm{D}$ cell culture is a very different situation compared to cells cultured on microcarriers. For instance, among other 
differences, the increased time required for ADSCs to adhere to PAMs could likely lead to a delay in the start of cell proliferation after cell seeding in respect to the $2 \mathrm{D}$ condition.
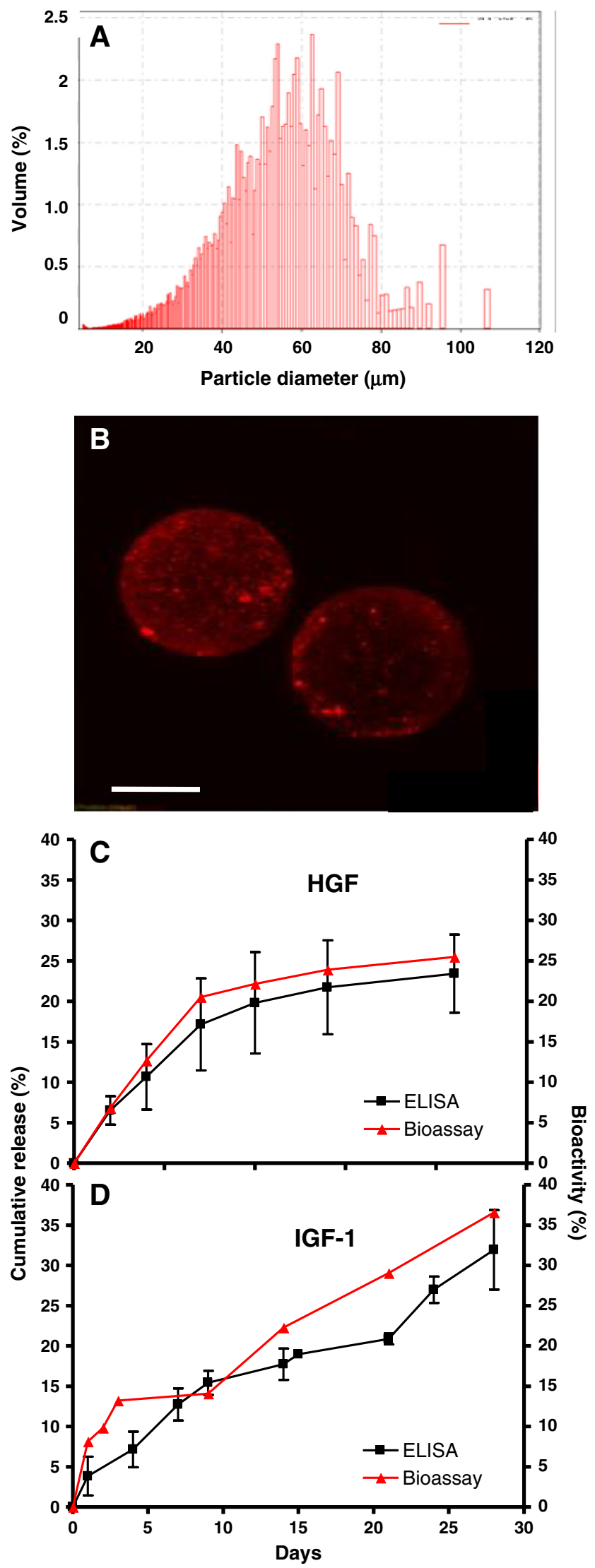

\section{6. mRNA expression of ADSCs adhered onto LM-PAM-GFs}

We cultured ADSCs on PAMs with a LM biomimetic surface (LM-PAMs) or on a mix of equal amounts of LM-PAMs releasing GFs (LM-PAM-HGF and LM-PAM-IGF-1) for 1 week to induce a cardiomyogenic commitment. Indeed, HGF and IGF-1 have been shown to induce cardiomyogenic differentiation of MSCs and survival of cardiomyocytes [13,34,41]. Incubation of $4 \times 10^{5}$ ADSCs with $0.5 \mathrm{mg}$ LM-PAMs allowed the rapid adhesion of the cells onto the surface of the microspheres. Adhesion was similar whether LM-PAMs released or not HGF and IGF-1. Indeed, as soon as $2 \mathrm{~h}$ after incubation, most of the cells adhered on the LM-PAMs with almost no cells in suspension (not shown). Initial LM-PAM/cell complexes adhered between themselves and formed spheroids that became bigger with time, so that all the cells were entrapped within 3D LM-PAM/cell complexes; no cells in suspension could be observed at any time after day 2 .

To ascertain whether ADSCs were committed toward cells other than cardiomyocytes we performed a qRT-PCR analysis of markers of cells different from cardiomyocytes at week 1 . Four groups were tested ( $\mathrm{n}=4$ each in triplicate): ADSC, ADSC + PAM, ADSC + PAM + GF, and $\mathrm{ADSC}+\mathrm{PAM}+\mathrm{GF}$ in $22 \% \mathrm{HG}$, where PAMs were covered with laminin. Col2a1 was absent in all groups. BGLAP was only slightly expressed in ADSCs and tended to further decrease with PAMs \pm GFs and $\pm \mathrm{HG}$ in respect to ADSCs alone. The expression of FABP4 was also very low in ADSCs, doubled in the presence of PAMs, but did not change with $\mathrm{PAM}+\mathrm{GF}$ nor with PAM + GF + HG. TUBB3 is the molecule which was mostly expressed by ADSCs and increased about three times with PAMs. It increased two times with PAM + GF and remained unchanged with PAM + GF + HG. PECAM1 expression was extremely low in ADSCs. PECAM1 increased about 35 times with PAMs or PAM + GF, but was almost undetectable with PAM + GF + HG (data not shown).

The mRNA expression of Cyclin D1 and several cardiac markers was studied at week 1 to evaluate whether cells progressed in cell cycle, differentiated, and were affected by P407 (Fig. 4). The transcripts of Nkx2.5, GATA4 and cTnI were not expressed in all conditions (data not shown). The cell-cycle Cyclin D1 mRNA was very slightly expressed under basal conditions. Its levels increased when ADSCs were adhered on LM-PAMs particularly when cells were grown on LM-PAMs releasing GFs. The mRNA of MEF2C was already expressed in ADSCs cultured under standard conditions, as previously described [38] and its levels tended to decrease in the presence of LM-PAMs \pm GFs. SERCA2a was only slightly expressed under all conditions. By contrast, the control levels of CX43 mRNAs were already highly expressed and showed an increasing trend with ADSCs growing on LM-PAMs and LM-PAMs plus GFs.

We also studied whether the P407 HG could influence ADSC commitment toward the cardiomyogenic lineage when adhered onto PAMs for 1 week. A significant decrease of the mRNA levels of Cyclin D1 was observed in ADSC-PAM-GF complexes within the $22 \%$ HG compared to ADSC-PAM-GF alone, suggesting that fewer cells were proliferating. A similar decrease characterized MEF2C and SERCA2a mRNAs,

Fig. 2. PAM characterization and GF release profile. PAM size distribution was bell-shaped and had an average diameter of $60 \mu \mathrm{m}(\mathrm{A})$. The surrounding biomimetic coating was homogenously distributed at their surface as shown by the confocal image of laminin immunofluorescence (B, scale bar $=25 \mu \mathrm{m}$ ). At each time-point, the released HGF $(C)$ and IGF-1 (D) were quantified by ELISA (black line) and their bioactivity was evaluated by an in vitro bioassay (red line). Values in C and D represent the GF cumulative release and are expressed as percent mean \pm SD of the total GF encapsulated into PAM (100\%). A continuous release of HGF from PAMs was observed for at least 21 days, representing $24 \%$ of the entrapped protein (C). The released HGF maintained its native bioactivity as shown by the overlapping profiles of the ELISA and bioassay curves. IGF- 1 shows a cumulative release of $32 \%$ after 28 days and a bioactivity profile comparable to that of the native IGF-1 (D). (For interpretation of the references to color in this figure legend, the reader is referred to the web version of this article.) 
Table 3

Elastic moduli and transition temperatures of different concentrations of P407.

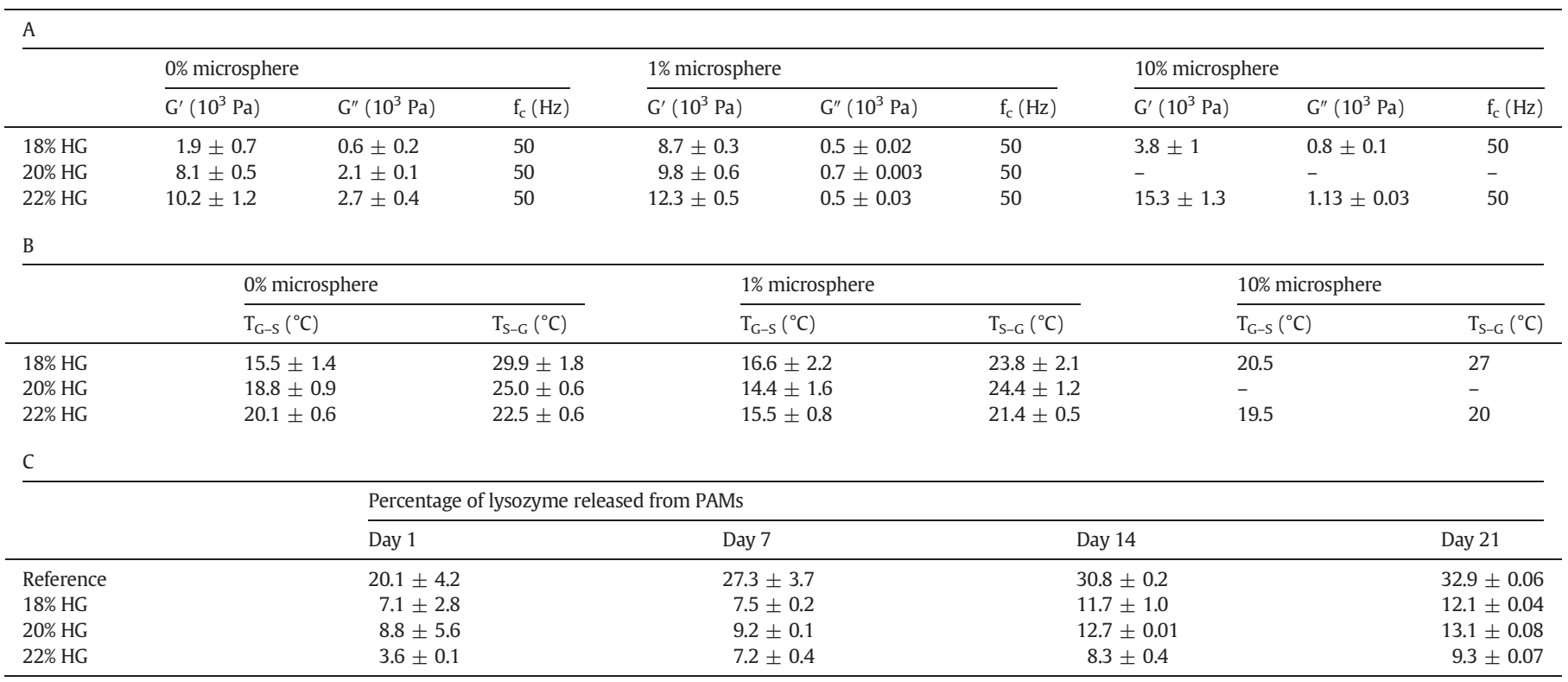

$\mathrm{G}^{\prime}$ and $\mathrm{G}^{\prime \prime}$ - elastic and viscous modulus at $0.1 \%$-constant strain and $1 \mathrm{~Hz}$-constant frequency; $\mathrm{f}_{\mathrm{c}}-$ critical frequency where gel properties are lost at $0.1 \%$-constant strain.

TG-S and TS-G - gel-solution and solution-gel transition temperatures at 0.1\%-constant strain and $1 \mathrm{~Hz}$ constant frequency.

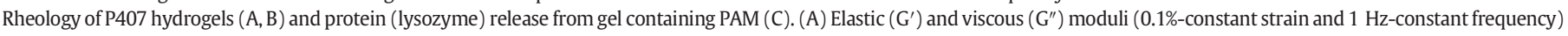

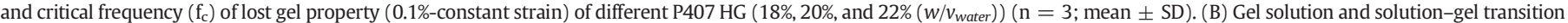

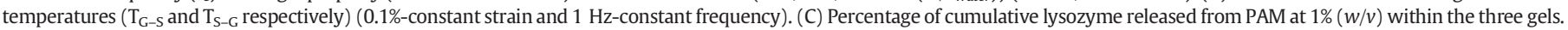
The reference is the cumulative release of lysozyme from PAM in release buffer without gel ( $\mathrm{n}=3$; mean \pm SD).

which were both very slightly expressed when the complexes were within the HG. Interestingly, a significant increase in CX43 was observed in ADSC-PAM-GF complexes within HG compared to ADSCs alone, leading to a strong expression of this molecule that suggests the formation of well-integrated gap-junction communications between the cells.

\subsection{Immunostaining of cardiac markers in ADSCs adhered onto LM-PAM-GFs}

After immunostaining, we observed that GATA4 and CX43 proteins were slightly expressed in ADSCs grown on LM-PAMs (Fig. 5A) but the other markers were not present (data not shown). In contrast, under culture conditions with LM-PAMs releasing GFs, ADSCs were highly stained with MEF2C, CX43 (Fig. 5B), cTnI and GATA4 (Fig. 5C). Due to its 3D conformation, a confocal microscopy observation was performed to better evaluate the distribution of the cells expressing the cardiac markers within the complexes formed by LM-PAMs releasing GFs and ADSCs.

CX43 and GATA4 were expressed throughout the complex (Fig. 5D and I) while cTnI was expressed at the periphery of the complex (Fig. 5E). Ki67-positive cells were also observed at the center and throughout the complex (Fig. 5H). This marker distribution was confirmed by merging images (Fig. 5F, G, J). Fig. 6 shows the expression of CX43 and Nkx2.5 in the ADSC-PAM-GF complexes at higher magnification. Finally, the estimation of the proportion of cells expressing cardiac markers in ADSCs grown on LM-PAM releasing GFs confirmed that an elevated number of cells were committed to the cardiac lineage (Table 4).

\section{Discussion}

The use of adult stem cells for cardiac cell therapy combined to biodegradable injectable 3D-biomimetic scaffolds, releasing growth factors in a prolonged manner, holds great promises to overcome the poor regenerative capacity of the damaged heart $[1,10,42]$. In this study, we developed PAMs with a biomimetic surface composed mainly of LM as bioadhesive, cardiomyocyte differentiation-inducing component for ADSCs [24]. In addition these LM-PAMs deliver in a prolonged manner, either IGF-1 or HGF which are validated for cardiac tissue engineering as angiogenic, differentiation, and pro-survival factors [8,43-45]. We obtained the proof of principle that a mix of LM-PAMs delivering HGF and IGF-1 induced in vitro the differentiation of adult stem cells toward the cardiomyogenic lineage. These results are essential to be able to further evaluate the effect of ADSC-PAM-GF complexes injected within a thermosensitive $\mathrm{HG}$ on cardiac repair of the ischemic heart.

Although encouraging results have been reported in cardiac cell therapy studies, only a few of the transplanted cells survive and integrate into the host myocardium. Recent studies with HG, microparticles and other scaffolds conveying cells and releasing GFs have shown improvements in cardiac function in vivo $[1,42,46-48]$. Although interesting results are obtained, the amount of GF released and the release profile are not well documented. Moreover, to appropriately implement these approaches for cardiac tissue engineering, it is essential to obtain a sustained GF release from such scaffolds at physiological and controlled doses. In this way, the GF and cells may not only initiate tissue repair, but also exert their trophic effects during the entire process. In this work, we developed a 3D scaffold with an instructive biomimetic coating of LM and releasing continuously a known concentration of either HGF or IGF-1 over time. We have recently shown that a 3D-laminin biomimetic support provided by PAMs stimulate cardiomyogenic commitment when the appropriate GFs are added to the medium (submitted article) [49]. The LM-PAMs were implemented to release during their degradation similar concentrations of GFs to those used in the GF cocktail for 1 week.

To obtain a complete and sustained release of an active protein it is necessary to protect it during the encapsulation and release process 
A
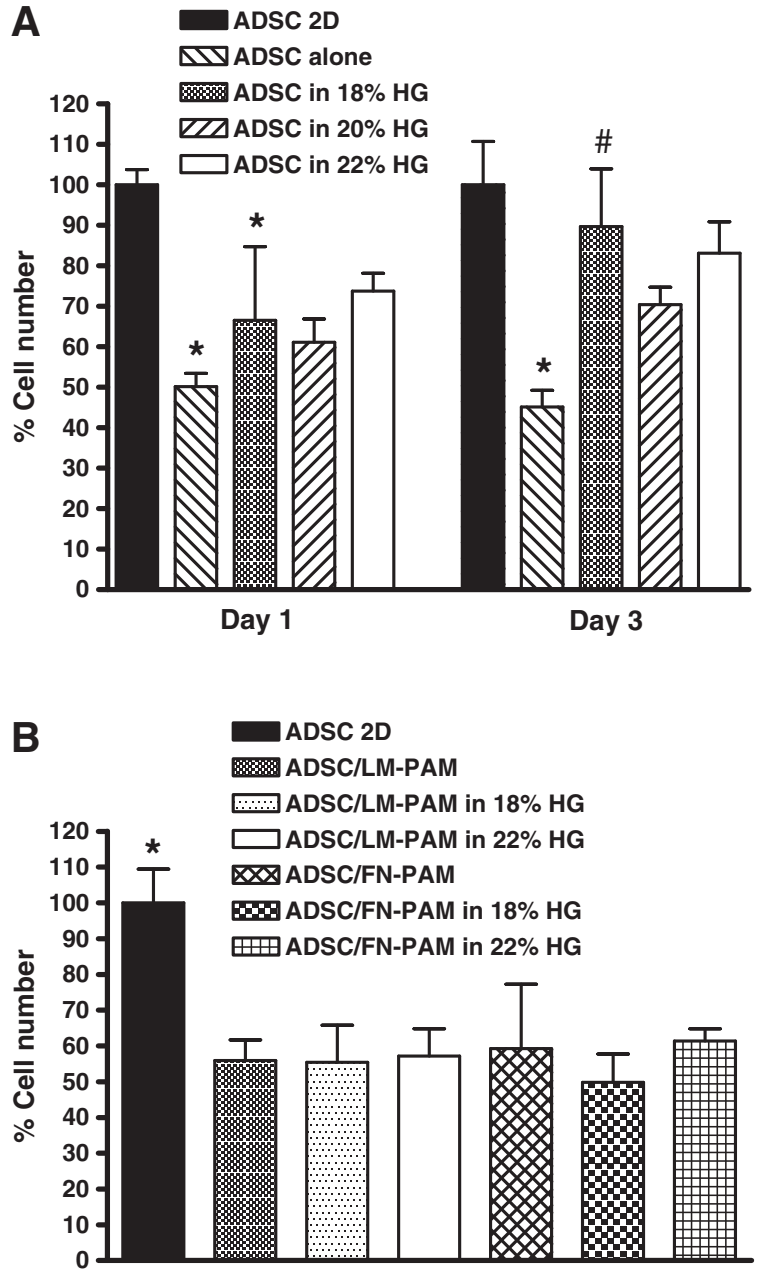

Fig. 3. Quantification of ADSCs in P407. The number of ADSCs was calculated by the Cyquant assay and expressed as percentage of the amount of cells grown under standard $2 \mathrm{D}$ conditions ( $\mathrm{ADSC} 2 \mathrm{D}=100 \%$ ). (A) The assay was performed using cells suspended in standard medium (ADSC alone) or grown in the hydrogel P407 (HG) at concentrations of $18 \%, 20 \%$, and $22 \%$, up to 3 days. (B) The cell number was also evaluated using ADSCs adhered on FN-PAMs in the absence or presence of different concentrations of P407. * $\mathrm{p}<0.05$ vs ADSC 2D; \#p < 0.05 vs ADSC alone.

[50-52]. To preserve protein integrity during the PLGA microsphere preparation, we have developed a technique that maintains the protein in a solid state, where it is less fragile and exhibits restricted conformational flexibility. Due to the expensive cost of therapeutic proteins, model proteins with similar physico-chemical properties were used to predict their precipitation environment as proposed by Giteau et al. [29]. We found that by placing the protein at $4{ }^{\circ} \mathrm{C}$ in a solution at a pH corresponding to its isoelectric point and at a particular range of saltinduced ionic strength, the glycofurol induced the protein precipitation. Moreover, this precipitation could be visualized at a minimum protein concentration of $5.5 \mathrm{mg} / \mathrm{mL}$ for these GFs, particularly for the small polypeptide, IGF-1. In these conditions, a good precipitation efficiency of $90 \pm 10.3 \%$ for HGF and $81 \pm 20 \%$ for IGF-1 (Table 2 ) was obtained. To limit adsorption onto the hydrophobic PLGA, these GFs were coprecipitated with poloxamer 188 and encapsulated within PAMs with a homogenous biomimetic coating of LM. An initial burst followed by a continuous release of around $25 \%$ of the encapsulated protein was observed for the two proteins for at least 3 weeks.

The first step of the release profile of both proteins was quite similar since it was $13 \%$ for IGF-1 and $17 \%$ for HGF at day 7 . The incomplete release of the HGF was partially due to protein aggregation under an acidic environment due to polymer degradation leading to a plateau at $23 \%[27,30]$. The release profile of both proteins was quite similar as it was mainly controlled by the degradation rate of the polymer [30,53]. The plateau was not observed for the polypeptide IGF-1, which was continuously released after 3 weeks, probably due to its smaller size and better stability compared to complex conformation of proteins. Nevertheless, for $1 \mathrm{mg}$ PAMs, which constitute an easily implantable quantity, we obtained a sustained release of around $344 \mathrm{ng} / \mathrm{mL}$ of HGF and $320 \mathrm{ng} / \mathrm{mL}$ of IGF-1 for 3 weeks, corresponding to physiological doses of the GFs. In this study we used blank PAMs, not releasing GFs or HSA used as a carrier protein within the PAMs, as controls of GFreleasing PAMs as previously reported [23-28,54]. Indeed, HSA has no effect on the survival or differentiation of the cells which are the parameters being evaluated.

Interestingly, a recent study has described the effect of the dual delivery of IGF-1 followed by HGF in a sequential manner from affinity binding alginate hydrogels [55]. They observed cardiomyocyte cycle activation and a cytoprotective effect in vitro. Additionally, when injected in the infarcted rat heart, a significant reduction of the fibrotic area and apoptotic cells was observed along with an increase in vessel density and proliferating cardiomyocytes compared to controls. Another recent study has described the role of injection of HGF and IGF-1 in endogenous cardiac progenitor cell recruitment and proliferation within the infarcted area [35]. Although very interesting results have been obtained with these GFs, to our knowledge they have not already been used together in combination with ADSCs. These cells could contribute to the repair process either directly after their engagement into a cardiomyocyte lineage or indirectly by the secretion of tissue repair cytokines. In this regard, HGF has been described as an inductor of embryonic stem cells and MSC differentiation into cardiomyocytes [13-56]. It has been demonstrated that in vitro addition of $20 \mathrm{ng} / \mathrm{mL}$ HGF induced mouse MSC commitment into the cardiac lineage [13].

In our study we observed that LM-PAMs, conveying ADSCs and releasing HGF and IGF-1, could induce ADSC commitment into cardiac lineage, while stimulating their proliferation, in respect to the same complex without GFs. We do not exclude that ADSCs differentiate also into cells, which are different from cardiomyocytes, e.g. endothelial, osteogenic, adipogenic, and smooth muscle cells, but IGF-1 and HGF are not specific for these lineages. In fact, it is necessary to use cocktails of GFs which are different from IGF-1 and HGF, along with other compounds, to obtain such differentiations [57]. When ADSCs were cultured for 1 week on LM-PAMs releasing HGF and IGF-1 in vitro, the protein expression of cardiac transcription factors GATA4 and MEF2C was induced. Also the protein expression of sarcomeric cTnI and gap junction GJA1/CX43 increased, indicating a late-stage cardiac differentiation of the adhered cells. Interestingly, Ki67 and GATA-4 expressing cells were located also in the center of the complexes while cTnI expressing cells were found in the periphery, indicating that the release of GFs may be correlated with cell differentiation. Indeed, the GFs are released from the PAMs during polymer hydrolysis, which is more pronounced in the periphery of the complexes. CX43, which was highly expressed in these conditions, was found to be homogeneously distributed within and all around the complexes suggesting gap-junction communication of the cells. It has been recently demonstrated that a local injection of HGF and IGF-1 decreased stress-induced arrhythmias in ischemic rat heart by reducing negative structural remodeling and generating electromechanically-connected myocytes 2 weeks after GF injection [36]. It is interesting to note that the proteins released from PAMs could be delivered at similar concentrations to those used in Bocchi et al.'s study for a longer period and without degradation [36].

Concerning the transcript expression of these markers in the presence of GFs, we observed only a slight increasing tendency for SERCA2a and CX43 in ADSCs adhered to LM-PAMs, which however did not reach statistical significance. Moreover, no variation was induced by GFs to GATA4, Nkx2.5 and cTnI mRNAs since they were not 


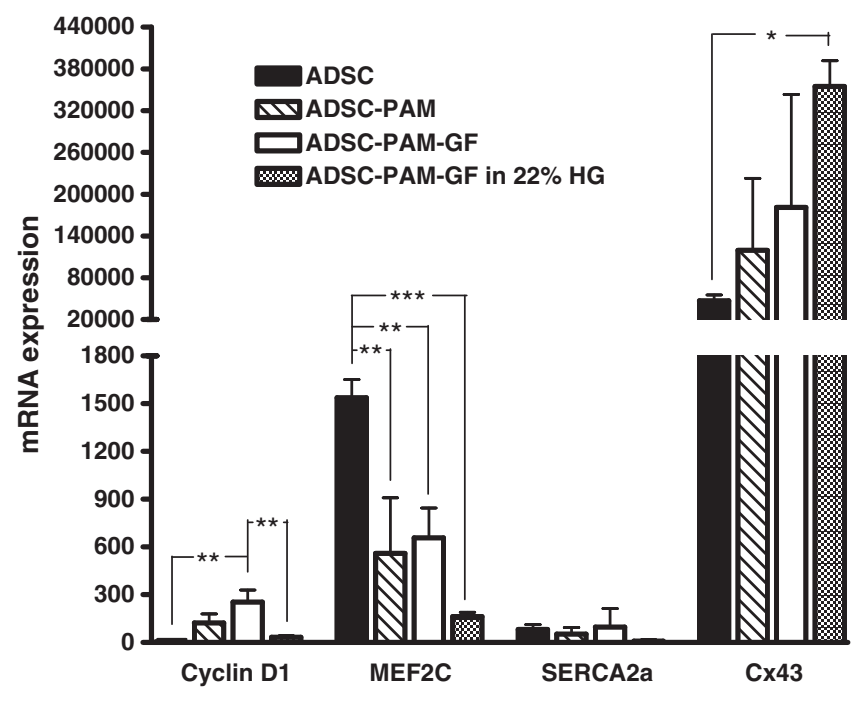

Fig. 4. Transcript expression of cardiac and cell cycle markers in ADSCs adhered on LM-PAMs releasing GFs and embedded in P407. The mRNA levels of markers of cardiac commitment and cell cycle were evaluated at week 1 by comparing cells grown under standard condition (ADSC) to cells adhering to LM-PAMs without GFs (ADSC-PAM), or to equal amounts of LM-PAMs releasing HGF and IGF-1 (ADSCPAM-GF), or to LM-PAMs releasing GFs in P407 (ADSC-PAM-GF in 22\% HG). The increased mRNA of Cyclin D1 in ADSC-PAM-GF suggests that HGF and IGF-1 stimulated cell cycle progression, but the presence of $22 \%$ P407 abolished this effect. The mRNA of MEF2C was already highly expressed in ADSCs grown in 2D while its abundance was reduced in the other conditions, especially in the presence of P407. The mRNA level of SERCA2 was rather low in all conditions; on the contrary, CX43 mRNA was highly expressed in standard ADSCs and showed a further significant increase in the ADSC-PAM-GF complexes embedded into P407. Values are expressed as mean \pm SD of qRT-PCR arbitrary units, normalized as fold increase in respect to the reference gene expression, GAPDH. ${ }^{*} \mathrm{p}<0.05$; ${ }^{* *} \mathrm{p}<0.01$; $^{* * *} \mathrm{p}<0.001$. All comparisons within each marker group that do not show symbols of statistical analysis are not significantly different.

expressed at week 1 in all conditions tested. Nevertheless, the lack of expression of these mRNAs at week 1 does not exclude that they could transitorily be present during the first week of treatment and this would justify the synthesis of the corresponding proteins observed at week 1 . As a matter of fact, mammalian proteins are on average five times more stable and 2800 times more abundant than mRNAs [58]. It is known that GATA4 protein has a long half-life in most tissues [59] and its partial stability could explain its abundance in the stimulated ADSCs despite the absence of the corresponding mRNAs. Moreover, changes in protein levels are not always accompanied by changes in corresponding mRNAs, as recently reported for embryonic stem cells [60]. In the matter of the reduced expression of MEF2C mRNA in the ADSC-PAM-GF complexes in respect to ADSCs grown in 2D, we cannot exclude that low cellular levels of this transcription factor could still have a high activity if residing in the nucleus rather than in the cytosol. An indirect confirmation that MEF2C, and also GATA4, reached the nucleus of the ADSCs when stimulated by the HGF and IGF-1, was the parallel expression of $\mathrm{CTnI}$ in the ADSC-PAM-GF complexes. Indeed, this sarcomeric protein is an absolute and exclusive marker of cardiomyocytes and its transcription can be achieved only if GATA4 and MEF2C are bound to the consensus sequences of the promoter $[61,62]$. A more direct proof that GATA4 moved into the nucleus was provided by the confocal images, looking at its merged co-localization with Ki67, a nuclear protein which cannot reside in the cytosol (Fig. 5J).

However, the mRNA level of MEF2C was already significantly expressed in ADSCs grown in 2D, while the SERCA2 transcripts were rather low, and those of GATA4, Nkx2.5 and cTnI even absent, in all conditions. This suggests that our treatments did not stimulate cardiac differentiation compared to standard ADSCs and, therefore, we cannot conclude that LM-PAMs, per se, induce the expression of cardiac muscle markers in ADSCs. On the other hand, as shown by the immunocytochemistry, the sustained release of HGF and IGF-1 can stimulate cardiac commitment in ADSCs when they adhere to LM-PAMs.

With regard to other possible kinds of differentiation that could be the consequence of our treatments, we observed that PAMs releasing GFs $\pm 22 \% \mathrm{HG}$ did not induce adipogenesis, osteogenesis, and chondrogenesis in ADSCs, but only a slight endothelial and neuronal cell differentiation. However, some commitment of ADSCs toward these latter two cell lineages could contribute as well to the regeneration of vascular and neural cardiac components that are usually injured together with cardiomyocytes after an ischemic insult.

ADSC proliferation also seemed to be positively affected by LMPAMs releasing GFs confirming their well-known mitogenic activity in most cell types $[63,64]$. Cyclin D1 mRNA expression increased under this condition in respect to ADSCs alone cultured in 2D, and the Ki67 protein staining showed a widespread distribution in the ADSC-PAMGF complexes.

The use of an injectable thermosensitive HG is an interesting approach because it could mechanically support the beating myocardium without interfering with the electric signal conduction. Integrating PAMs releasing a protein in a thermosensitive injectable hydrogel of P407 resulted in a slower release profile (Table 3C). This phenomenon is due to an increase in chain entanglement and gel formation that favors hydrophobic interactions. This entanglement is also more marked at higher concentrations of P407, yielding an increase in gel strength and consequently a decrease of the drug release rate. However, there seemed to be no specific interaction between PAMs and the P407 HG. The transition temperatures were not modified with the addition of PAMs, meaning a similar crosslinking number and nature polymer chains, whatever the amount of PAMs. Moreover, the viscoelastic properties are augmented when $1 \% w / v$ of PAMs is added within the gel. When the amount of PAMs within the HG was increased to reach the injection concentrations of PAMs generally used for in vivo experiments [22], a slight increase in the elastic modulus was observed with the HG at a higher concentration (22\%). On the contrary, the elastic modulus of the $18 \%$ HG decreased, indicating the loss of the viscoelastic behavior of the HG which is probably due to a loss of structure. Interestingly, P407 viscoelastic properties obtained with the $22 \% \mathrm{HG}$ $(15.3 \pm 1.3 \mathrm{kPa})$ are close to those used in the literature to demonstrate the effect of matrix stiffness on cell fate [10,43-46]. Indeed, it has been described that playing on matrix elasticity properties, stem cells can be induced into a defined lineage in a viscoelastic-dependent manner $[65,66]$. Although the normal modulus of the heart is approximately in the range of $10-20 \mathrm{kPa}$, gels with a $10-13 \mathrm{kPa}$ induced MSCs toward a muscular phenotype without the need of additional molecular signals [67]. An elastic modulus of $65 \mathrm{kPa}$ is needed to induce cardiac differentiation of MSCs cultured for 2 weeks within a synthetic thermosensitive HG [68], reinforcing the importance of the substrate stiffness. As the $22 \%$ HG with the PAMs has an elastic modulus within the range of 12-15 $\mathrm{kPa}$, similar to that of the heart, the cells adhered onto the 3D support provided by the PAMs contained inside the gel could be first induced toward a myogenic lineage and furthermore into a cardiomyogenic commitment with the appropriate differentiating signals released from the PAMs. Moreover, although the addition of PAMs into the gel did not modify the elastic modulus, its elasticity was increased as measured by the increase of the $G^{\prime} / G^{\prime \prime}$ ratio suggesting that PAMs integrated within the HG would have sufficient elasticity to support the beating myocardium and appropriate stiffness to help induce ADSC commitment toward the cardiomyogenic lineage.

We first evaluated the number of cells within the HG and observed that it was maintained for 3 days due to the 3D support provided by the gel. At high gel concentration, the HG slightly increased the cell number when ADSC/PAM complexes were incorporated within the gel compared to these complexes alone. We then evaluated whether the $22 \%$ P407 hydrogel could influence the proliferation of ADSCs, adhered on LM-PAMs releasing GFs, into the cardiomyogenic lineage after 

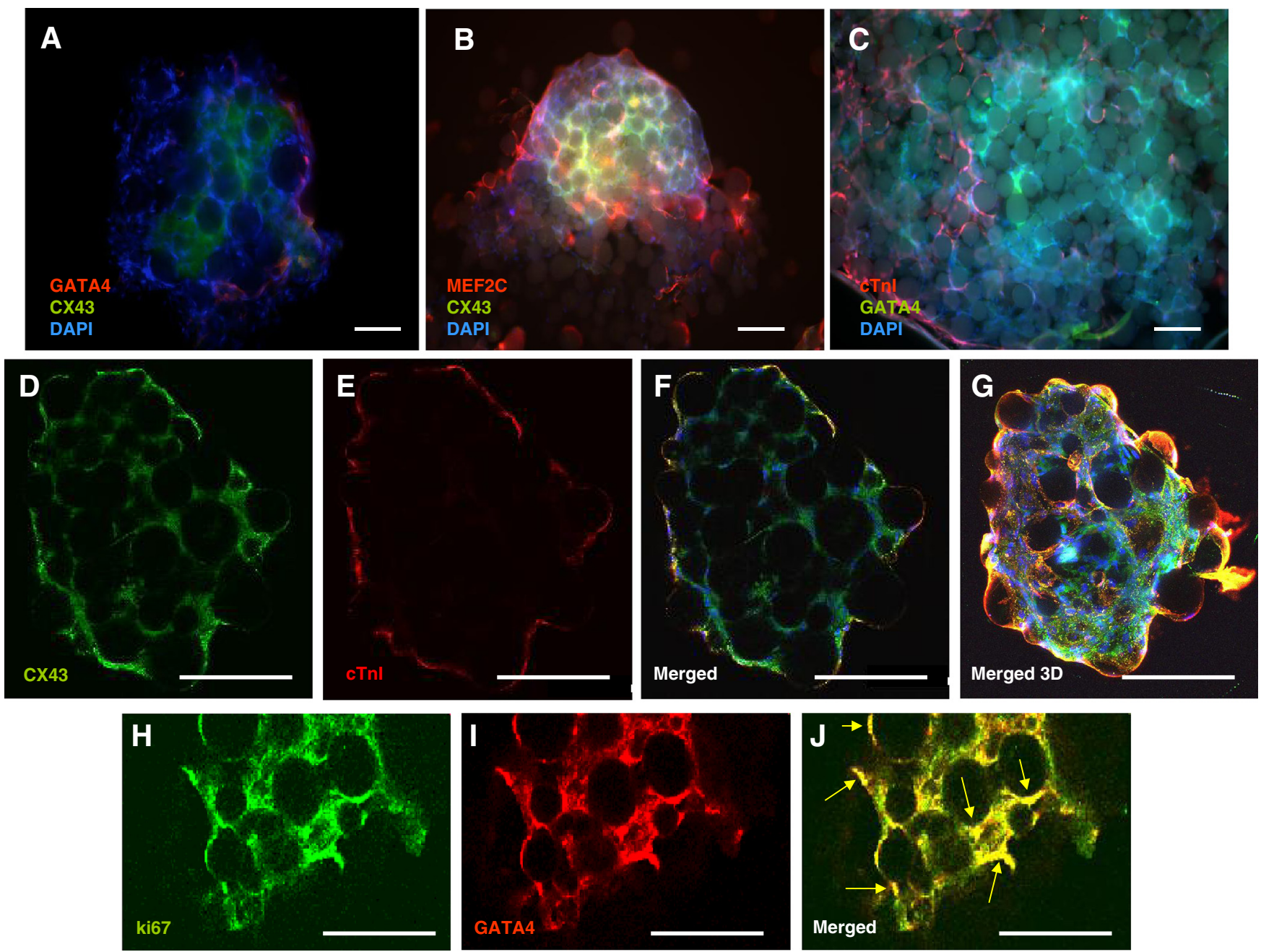

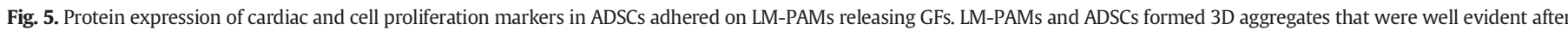

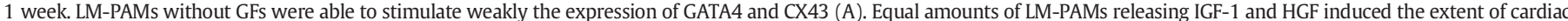

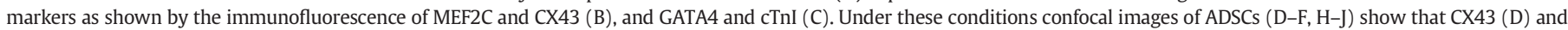

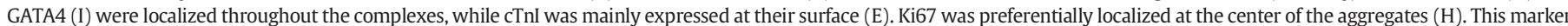

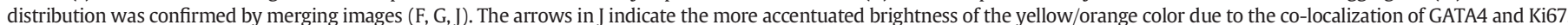

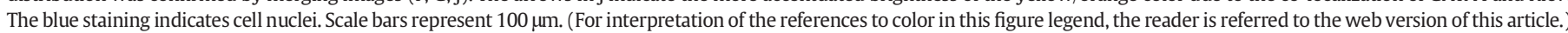

1 week. In this condition, the mRNA levels of the cell-cycle molecule, Cyclin D1, decreased compared to the ADSC/PAM complexes alone releasing or not GFs, suggesting fewer proliferating cells, probably due to a more elastic environment provided by the HG. Although the effect of substrate stiffness on Cyclin D1 expression has already been reported when mouse embryo fibroblasts, MCF10A mammary epithelial cells, vascular smooth muscle cells and osteoblastic cells were plated on FNcoated hydrogels for $48 \mathrm{~h}$ [69], to our knowledge, it has not been described in differentiating conditions combining HG and GFs. To further study the commitment of ADSCs in these conditions, the mRNAs of the cardiac transcription factors were evaluated. The mRNAs of Nkx2.5 and GATA4 were not expressed and a decrease in the expression of their cofactor, MEF2C, was observed. As the protein delivery is lower within the gel we could assume that the release of the GFs is diminished within the gel also explaining the decreased expression of these molecules. Therefore the amount of protein release needs to be adapted to these conditions, for instance by increasing its concentration within PAMs and/or modifying the PLGA composition in order to accelerate the delivery to cells of the encapsulated GFs.

Gap junctional coupling is essential in establishing electrochemical communications between cardiomyocytes. CX43, the major gap junction protein of the working myocardium, is involved in cardiac development, i.e. by transferring cardiomyogenic signals within cardiomyocytes [70-72]. Lack of such protein results in serious cardiac malformation during development and is correlated to the arrhythmic phenomenon encountered following cell transplantation [46-48,73]. The presence of CX43-expressing cells in PAM complexes represents a further advantage for cell therapy, as it should allow a better ADSC engraftment and communication with host cells. Additionally, as its expression is highly increased when the ADSC-PAM-GF complexes are integrated within an injectable thermosensitive hydrogel, we can hypothesize that the transplanted cells would better engraft and home within the infarcted area.

In conclusion, these results suggest that PAMs with a biomimetic coating of LM, releasing bioactive HGF and IGF-1 can be used as a tool to convey cells and repair the infarcted heart. PAMs releasing HGF and IGF-1 are able to induce the expression of both early and late cardiac muscle markers when ADSCs are adhered on their surface. Even though a slower protein release profile is supposed when the PAMs are integrated within the HG, an increase in CX43 expression is detected in ADSC-PAM-GF complexes within the non-toxic HG, suggesting the possibility of communication between these cells. Therefore, PAMs covered 

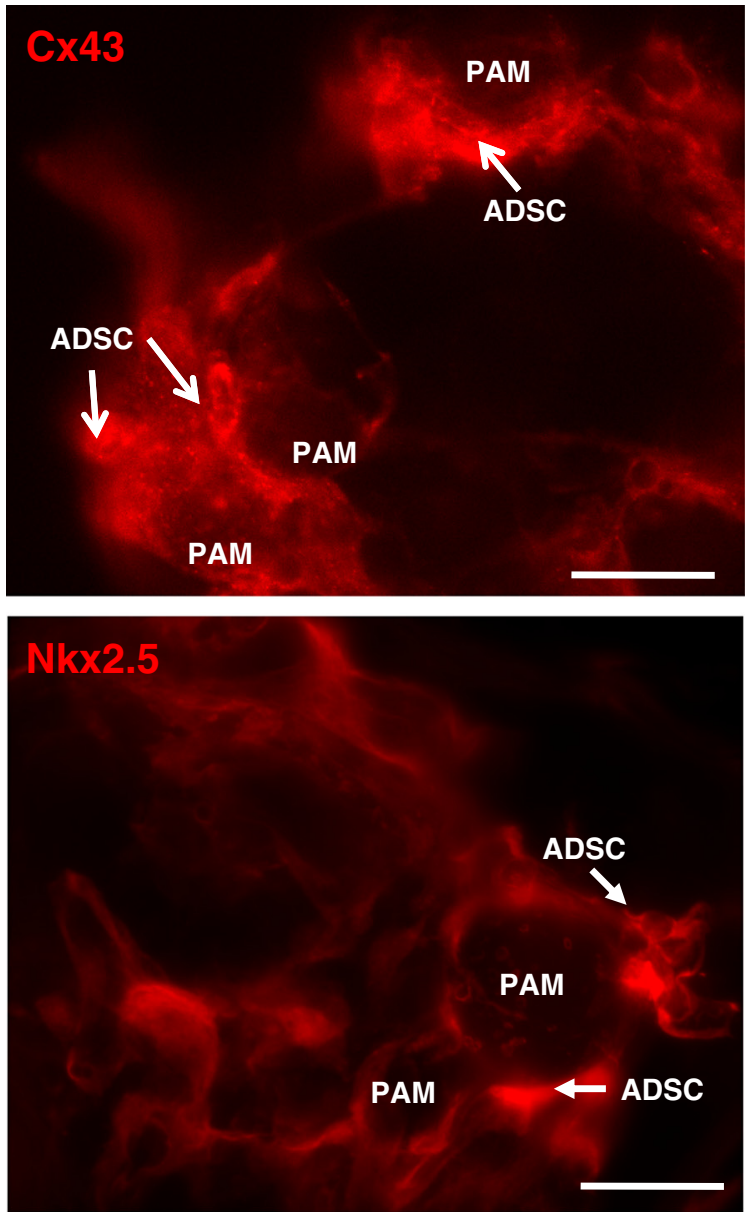

Fig. 6. CX43 and Nkx2.5 staining in ADSCs adhered on LM-PAMs. The marked expression of CX43 and Nkx2.5 can be appreciated in the ADSC-PAM-GF complexes obtained under the same conditions described in Fig. 5. Arrows indicate the stained cells adhering to LMPAMs and releasing GFs for 1 week. Scale bars represent $50 \mu \mathrm{m}$.

by LM, conveying ADSCs and releasing IGF-1 and HGF within a thermosensitive hydrogel may favor cell communication, influencing the recovery of cardiac function and proneness to arrhythmias in a manner that needs to be tested.

\section{Acknowledgments}

We thank the SCIAM ("Service Commun d'Imagerie et d'Analyse Microscopique") of Angers for the confocal microscopy images as well as the SCCAN ("Service Commun deCytométrie et d'Analyse Nucléotidique") of Angers for the use of PCR facilities. Grant

Table 4

Labeling of ADSCs adhered on LM-PAMs plus GFs.

\begin{tabular}{ll}
\hline Cx43 & +++ \\
Nkx2.5 & +++ \\
MEF2C & ++ \\
GATA4 & +++ \\
CTnI & + \\
Ki67 & + \\
\hline
\end{tabular}

$+: 2-50$ cells

$++: 100-150$ cells.

$+++: 150-200$ cells.

ADSCs were cultured on equal amounts of LMPAMs releasing HGF and IGF-1 for 1 week. Cells showing the immunofluorescence of each selected cardiac marker were counted at $40 \times$ in four different areas. information: This work was supported by "Angers Loire Métropole", "Institut National de le Recherche et de la Sante Medical (INSERM)", France, the National Institute for Cardiovascular Research (INRC) and Fondazione dott. Carlo Fornasini (Poggio Renatico, FE), Italy.

\section{References}

[1] V. Segers, R.T. Lee, Stem-cell therapy for cardiac disease, Nature 451 (2008) 937-942.

[2] E. Marban, K. Cheng, Heart to heart: the elusive mechanism of cell therapy, Circulation 2010 (121) (2010) 1981-1984.

[3] M. Govoni, C. Muscari, C. Guarnieri, E. Giordano, Mechanostimulation protocols for cardiac tissue engineering, Biomed. Res. Int. 2013 (2013) 918640.

[4] P. Menasché, Cardiac cell therapy: lessons from clinical trials, J. Mol. Cell. Cardiol. 50 (2011) 258-265

[5] R. Bolli, A.R. Chugh, D. D'Amario, J.H. Loughran, M.F. Stoddard, S. Ikram, G.M. Beache, S.G. Wagner, A. Leri, T. Hosoda, F. Sanada, J.B. Elmore, P. Goichberg, D. Cappetta, N.K. Solankhi, I. Fahsah, D.G. Rokosh, M.S. Slaughter, J. Kajstura, P. Anversa, Cardiac stem cells in patients with ischemic cardiomyopathy (SCIPIO): initial results of a randomised phase 1 trial, Lancet 378 (2011) 1847-1857.

[6] R.R. Makkar, R.R. Smith, K. Cheng, K. Malliaras, L.E. Thomson, D. Berman, L.S. Czer, L. Marbán, A. Mendizabal, P.V. Johnston, S.D. Russell, K.H. Schuleri, A.C. Lardo, G. Gerstenblith, E. Marbán, Intracoronary cardiosphere-derived cells for heart regeneration after myocardial infarction (CADUCEUS): a prospective, randomised phase 1 trial, Lancet 379 (2012) 895-904.

[7] J. Müller-Ehmsen, P. Whittaker, R.A. Kloner, J.S. Dow, T. Sakoda, T.I. Long, P.W. Laird, L. Kedes, Survival and development of neonatal rat cardiomyocytes transplanted into adult myocardium, J. Mol. Cell. Cardiol. 34 (2002) 107-116.

[8] K.H. Wu, X.M. Mo, Z.C. Han, B. Zhou, Stem cell engraftment and survival in the ischemic heart, Ann. Thorac. Surg. 92 (2011) 1917-1925.

[9] C. Muscari, F. Bonafè, S. Martin-Suarez, S. Valgimigli, S. Valente, E. Fiumana, F. Fiorelli, G. Rubini, C. Guarnieri, C.M. Caldarera, O. Capitani, G. Arpesella, G. Pasquinelli, Restored perfusion and reduced inflammation in the infarcted heart after grafting stem cells with a hyaluronan-based scaffold, J. Cell. Mol. Med. 17 (2013) 518-530.

[10] M.E. Padin-Iruegas, Y. Misao, D.E. Davis, V.F. Segers, G. Esposito, T. Tokunou, K. Urbanek, T. Hosoda, M. Rota, P. Anversa, A. Leri, R.T. Lee, J. Kajstura, Cardiac progenitor cells and biotinylated insulin-like growth factor-1 nanofibers improve endogenous and exogenous myocardial regeneration after infarction, Circulation 120 (2009) 876-887.

[11] K. Kitta, Hepatocyte growth factor induces GATA-4 phosphorylation and cell survival in cardiac muscle cells, J. Biol. Chem. 278 (2002) 4705-4712.

[12] J.Y. Hahn, H.J. Cho, H.J. Kang, T.S. Kim, M.H. Kim, J.H. Chung, J.W. Bae, B.H. Oh, Y.B. Park, H.S. Kim, Pre-treatment of mesenchymal stem cells with a combination of growth factors enhances gap junction formation, cytoprotective effect on cardiomyocytes, and therapeutic efficacy for myocardial infarction, J. Am. Coll. Cardiol. 51 (2008) 933-943.

[13] G. Forte, M. Minieri, P. Cossa, D. Antenucci, M. Sala, V. Gnocchi, R. Fiaccavento, F. Carotenuto, P. De Vito, P.M. Baldini, M. Prat, P. Di Nardo, Hepatocyte growth factor effects on mesenchymal stem cells: proliferation, migration, and differentiation, Stem Cells 24 (2006) 23-33.

[14] G. Srinivas, P. Anversa, W.H. Frishman, Cytokines and myocardial regeneration: a novel treatment option for acute myocardial infarction, Cardiol. Rev. 17 (2009) 1-9.

[15] J. Pons, Y. Huang, J. Arakawa-Hoyt, D. Washko, J. Takagawa, J. Ye, W. Grossman, H. Su, VEGF improves survival of mesenchymal stem cells in infarcted hearts, Biochem. Biophys. Res. Commun. 376 (2008) 419-422.

[16] C. Muscari, E. Giordano, F. Bonafè, M. Govoni, C. Guarnieri, Strategies affording prevascularized cell-based constructs for myocardial tissue engineering, Stem Cells Int (2014) 434169, http://dx.doi.org/10.1155/2014/434169.

[17] C. Borselli, H. Storrie, F. Benesch-Lee, D. Shvartsman, C. Cezar, J.W. Lichtman, H.H. Vandenburgh, D.J. Mooney, Functional muscle regeneration with combined delivery of angiogenesis and myogenesis factors, Proc. Natl. Acad. Sci. U. S. A. 107 (2010) 3287-3292.

[18] J. Saif, T.M. Schwarz, D.Y. Chau, J. Henstock, P. Sami, S.F. Leicht, P.C. Hermann, S. Alcala, F. Mulero, K.M. Shakesheff, C. Heeschen, A. Aicher, Combination of injectable multiple growth factor-releasing scaffolds and cell therapy as an advanced modality to enhance tissue neovascularisation, Arterioscler. Thromb. Vasc. Biol. 30 (2010) 1897-1904.

[19] S. Banquet, E. Gomez, L. Nicol, F. Edwards-Lévy, J.P. Henry, R. Cao, D. Schapman, B. Dautreaux, F. Lallemand, F. Bauer, Y. Cao, C. Thuillez, P. Mulder, V. Richard, E. Brakenhielm, Arteriogenic therapy by intramyocardial sustained delivery of a novel growth factor combination prevents chronic heart failure, Circulation 124 (2011) 1059-1069.

[20] Y. Hong, C. Gao, Y. Xie, Y. Gong, J. Shen, Collagen-coated polylactide microspheres as chondrocyte microcarriers, Biomaterials 26 (2005) 6305-6313.

[21] E. Garbayo, A.P. Raval, K.M. Curtis, D. Della-Morte, L.A. Gomez, G. D'Ippolito, T. Reiner, C. Perez-Stable, G.A. Howard, M.A. Perez-Pinzon, C.N. Montero-Menei, P.C. Schiller, Neuroprotective properties of marrow-isolated adult multilineageinducible cells in rat hippocampus following global cerebral ischemia are enhanced when complexed to biomimetic microcarriers, J. Neurochem. 119 (2011) 972-988.

[22] G.J. Delcroix, E. Garbayo, L. Sindji, O. Thomas, C. Vanpouille-Box, P.C. Schiller, C.N. Montero-Menei, The therapeutic potential of human multipotent mesenchymal stromal cells combined with pharmacologically active microcarriers transplanted in hemi-parkinsonian rats, Biomaterials 32 (2011) 1560-1573. 
[23] R. Pankov, K.M. Yamada, Fibronectin at a glance, J. Cell Sci. 115 (2002) 3861-3863.

[24] A. van Dijk, H.W. Niessen, B. Zandieh Doulabi, F.C. Visser, F.J. van Milligen, Differentiation of human adipose-derived stem cells towards cardiomyocytes is facilitated by laminin, Cell Tissue Res. 334 (2008) 457-467.

[25] V.M. Tatard, M.C. Venier-Julienne, P. Saulnier, E. Prechter, J.P. Benoit, P. Menei, C.N. Montero-Menei, Pharmacologically active microcarriers: a tool for cell therapy, Biomaterials 26 (2005) 3727-3737.

[26] C. Bouffi, O. Thomas, C. Bony, A. Giteau, M.C. Venier-Julienne, C. Jorgensen, C. Montero-Menei, D. Noël, The role of pharmacologically active microcarriers releasing TGF-beta3 in cartilage formation in vivo by mesenchymal stem cells, Biomaterials 31 (2010) 6485-6493.

[27] M. Morille, T. Van-Thanh, X. Garric, J. Cayon, J. Coudane, D. Noël, M.C. VenierJulienne, C.N. Montero-Menei, New PLGA-P188-PLGA matrix enhances TGF- $\beta 3$ release from pharmacologically active microcarriers and promotes chondrogenesis of mesenchymal stem cells, J. Control. Release 170 (2013) 99-110.

[28] C. Musilli, J.P. Karam, S. Paccosi, C. Muscari, A. Mugelli, C.N. Montero-Menei, A. Parenti, Pharmacologically active microcarriers for endothelial progenitor cell support and survival, Eur. J. Pharm. Biopharm. 81 (2012) 609-616.

[29] A. Giteau, M.C. Venier-Julienne, S. Marchal, J.L. Courthaudon, M. Sergent, C. MonteroMenei, J.M. Verdier, J.P. Benoit, Reversible protein precipitation to ensure stability during encapsulation within PLGA microspheres, Eur. J. Pharm. Biopharm. 70 (2008) 127-136.

[30] V.T. Tran, J.P. Karam, X. Garric, J. Coudane, J.P. Benoît, C.N. Montero-Menei, M.C. Venier-Julienne, Protein-loaded PLGA-PEG-PLGA microspheres: a tool for cell therapy, Eur. J. Pharm. Sci. 45 (2012) 128-137.

[31] A. Paillard-Giteau A, V.T. Tran, O. Thomas, X. Garric, J. Coudane, S. Marchal, I Chourpa, J.P. Benoît, C.N. Montero-Menei, M.C. Venier-Julienne, Effect of various additives and polymers on lysozyme release from PLGA microspheres prepared by an s/o/w emulsion technique, Eur. J. Pharm. Biopharm. 75 (2010) 128-136.

[32] Z. Li, T.X. Gu, Y.H. Zhang, Hepatocyte growth factor combined with insulin like growth factor-1 improves expression of GATA-4 in mesenchymal stem cells cocultured with cardiomyocytes, Chin. Med. J. (Engl.) 121 (2008) 336-340.

[33] G. Lu, H.K. Haider, S. Jiang, M. Ashraf, Sca-1 + stem cell survival and engraftment in the infarcted heart: dual role for preconditioning-induced connexin-43, Circulation 119 (2009) 2587-2596.

[34] K. Urbanek, M. Rota, S. Cascapera, C. Bearzi, A. Nascimbene, A. De Angelis, T. Hosoda, S. Chimenti, M. Baker, F. Limana, D. Nurzynska, D. Torella, F. Rotatori, R. Rastaldo, E. Musso, F. Quaini, A. Leri, J. Kajstura, P. Anversa, Cardiac stem cells possess growth factor-receptor systems that after activation regenerate the infarcted myocardium, improving ventricular function and long-term survival, Circ. Res. 97 (2005) 663-673.

[35] G.M. Ellison, D. Torella, S. Dellegrottaglie, C. Perez-Martinez, A. Perez de Prado, C. Vicinanza, S. Purushothaman, V. Galuppo, C. Iaconetti, C.D. Waring, A. Smith, M. Torella, C. Cuellas Ramon, J.M. Gonzalo-Orden, V. Agosti, C. Indolfi, M. Galiñanes, F. Fernandez-Vazquez, B. Nadal-Ginard, Endogenous cardiac stem cell activation by insulin-like growth factor-1/hepatocyte growth factor intracoronary injection fosters survival and regeneration of the infarcted pig heart, J. Am. Coll. Cardiol. 58 (2011) 977-986.

[36] L. Bocchi, M. Savi, G. Graiani, S. Rossi, A. Agnetti, F. Stillitano, C. Lagrasta, S. Baruffi, R. Berni, C. Frati, M. Vassalle, U. Squarcia, E. Cerbai, E. Macchi, D. Stilli, F. Quaini, E. Musso, Growth factor-induced mobilization of cardiac progenitor cells reduces the risk of arrhythmias, in a rat model of chronic myocardial infarction, PLoS One 6 (2011) e17750.

[37] G. Dumortier, J.L. Grossiord, F. Agnely, J.C. Chaumeil, A review of poloxamer 407 pharmaceutical and pharmacological characteristics, Pharm. Res. 23 (2006) 2709-2728.

[38] E. Ruel-Gariépy, J.C. Leroux, In situ-forming hydrogels-review of temperaturesensitive systems, Eur. J. Pharm. Biopharm. 58 (2004) 409-426.

[39] A. Pasini, F. Bonafè, M. Govoni, C. Guarnieri, P.G. Morselli, H.S. Sharma, C.M. Caldarera, C. Muscari, E. Giordano, Epigenetic signature of early cardiac regulatory genes in native human adipose-derived stem cells, Cell Biochem. Biophys. 67 (2013) 255-262.

[40] J. Vandesompele, K. De Preter, F. Pattyn, B. Poppe, N. Van Roy, A. De Paepe, F. Speleman, Accurate normalization of real-time quantitative RT-PCR data by geometric averaging of multiple internal control genes, Genome Biol. 3 (2002) (RESEARCH0034)

[41] A. Linke, P. Müller, D. Nurzynska, C. Casarsa, D. Torella, A. Nascimbene, C. Castaldo, S. Cascapera, M. Böhm, F. Quaini, K. Urbanek, A. Leri, T.H. Hintze, J. Kajstura, P. Anversa, Stem cells in the dog heart are self-renewing, clonogenic, and multipotent and regenerate infarcted myocardium, improving cardiac function, Proc. Natl. Acad. Sci. U. S. A. 102 (2005) 66-71.

[42] J.P. Karam, C. Muscari, C.N. Montero-Menei, Combining adult stem cells and polymeric devices for tissue engineering in infarcted myocardium, Biomaterials 33 (2012) 5683-5695

[43] M.E. Davis, P.C. Hsieh, T. Takahashi, Q. Song, S. Zhang, R.D. Kamm, A.J. Grodzinsky, P. Anversa, R.T. Lee, Local myocardial insulin-like growth factor 1 (IGF-1) delivery with biotinylated peptide nanofibers improves cell therapy for myocardial infarction, Proc. Natl. Acad. Sci. U. S. A. 103 (2006) 8155-8160.

[44] X.H. Chen, S. Minatoguchi, K. Kosai, K. Yuge, T. Takahashi, M. Arai, N. Wang, Y. Misao, C. Lu, H. Onogi, H. Kobayashi, S. Yasuda, M. Ezaki, H. Ushikoshi, G. Takemura, T. Fujiwara, H. Fujiwara, In vivo hepatocyte growth factor gene transfer reduces myocardial ischemia-reperfusion injury through its multiple actions, J. Card. Fail. 13 (2007) 874-883.
[45] M.S. Penn, U. Agarwal, IGF-1 and mechanisms of myocardial repair, Int. J. Cardiol. 38 (2010) 1-2.

[46] E. Ruvinov, J. Leor, S. Cohen, The promotion of myocardial repair by the sequential delivery of IGF-1 and HGF from an injectable alginate biomaterial in a model of acute myocardial infarction, Biomaterials 32 (2011) 565-578.

[47] T.D. Johnson, K.L. Christman, Injectable hydrogel therapies and their delivery strategies for treating myocardial infarction, Expert Opin. Drug Deliv. 10 (2013) 59-72.

[48] R. Censi, P. Di Martino, T. Vermonden, W.E. Hennink, Hydrogels for protein delivery in tissue engineering, J. Control. Release 161 (2012) 680-692.

[49] J.P. Karam, F. Bonafè, C. Muscari, C.N. Montero-Menei, Adipose-derived stem cell adhesion on laminin-coated microcarriers improves commitment toward the cardiomyogenic lineage, J. Biomed. Mater. Res. Part A (2014) (submitted for publication).

[50] C. Pérez, I.J. Castellanos, H.R. Costantino, W. Al-Azzam, K. Griebenow, Recent trends in stabilizing protein structure upon encapsulation and release from bioerodible polymers, J. Pharm. Pharmacol. 54 (2002) 301-313.

[51] A.L. Lewis, L. Illum, Formulation strategies for sustained release of proteins, Ther Deliv. 1 (2010) 457-479.

[52] L. Wang, Y. Liu, W. Zhang, X. Chen, T. Yang, G. Ma, Microspheres and microcapsules for protein delivery: strategies of drug activity retention, Curr. Pharm. Des. 19 (2013) 6340-6352.

[53] A. Giteau, M.C. Venier-Julienne, A. Aubert-Pouëssel, J.P. Benoit, How to achieve sustained and complete protein release from PLGA-based microparticles? Int. J. Pharm. 350 (2008) 14-26.

[54] C. Penna, M.G. Perrelli, J.P. Karam, C. Angotti, C. Muscari, C.N. Montero-Menei, P. Pagliaro, Pharmacologically active microcarriers influence VEGF-A effects on mesenchymal stem cell survival, J. Cell. Mol. Med. 17 (2013) 192-204.

[55] E. Ruvinov, J. Leor, S. Cohen, The effects of controlled HGF delivery from an affinitybinding alginate biomaterial on angiogenesis and blood perfusion in a hindlimb ischemia model, Biomaterials 31 (2010) 4573-4582.

[56] C. Roggia, C. Ukena, M. Böhm, H. Kilter, Hepatocyte growth factor (HGF) enhances cardiac commitment of differentiating embryonic stem cells by activating PI3 kinase, Exp. Cell Res. 313 (2007) 921-930.

[57] S.J. Huang, R.H. Fu, W.C. Shyu, S.P. Liu, G.P. Jong, Y.W. Chiu, H.S. Wu, Y.A. Tsou, C.W Cheng, S.Z. Lin, Adipose-derived stem cells: isolation, characterization, and differentiation potential, Cell Transplant. 22 (2013) 701-709.

[58] B. Schwanhäusser, D. Busse, N. Li, G. Dittmar, J. Schuchhardt, J. Wolf, W. Chen, M. Selbach, Global quantification of mammalian gene expression control, Nature 473 (2011) 337-342.

[59] R. Lu, F. Markowetz, R.D. Unwin, J.T. Leek, F.M. Airoldi, B.D. MacArthur, A. Lachmann, R. Rozov, A. Ma'ayan, Systems-level dynamic analyses of fate change in murine embryonic stem cells, Nature 462 (2009) 358-362.

[60] B. Thurisch, S.Y. Liang, N. Sarioglu, L. Schomburg, J. Bungert, C. Dame, Transgenic mice expressing small interfering RNA against Gata4 point to a crucial role of Gata4 in the heart and gonads, J. Mol. Endocrinol. 43 (2009) 157-169.

[61] R. Di Lisi, C. Millino, E. Calabria, F. Altruda, S. Schiaffino, S. Ausoni, Combinatorial cisacting elements control tissue-specific activation of the cardiac troponin I gene in vitro and in vivo, J. Biol. Chem. 273 (1998) (25371-15380).

[62] P.K. Bhavsar, K.A. Dellow, M.H. Yacoub, N.-J. Brand, P.J. Barton, Identification of cisacting DNA elements required for expression of the human cardiac troponin I gene promoter, J. Mol. Cell. Cardiol. 32 (2000) 95-108.

[63] R.M. Day, L. Soon, D. Breckenridge, B. Bridges, B.K. Patel, L.M. Wang, S.J. Corey, D.P. Bottaro, Mitogenic synergy through multilevel convergence of hepatocyte growth factor and interleukin-4 signaling pathways, Oncogene 21 (2002) 2201-2211.

[64] H. Yu, T. Rohan, Role of the insulin-like growth factor family in cancer development and progression, J. Natl. Cancer Inst. 92 (2000) 1472-1489.

[65] J.R. Tse, A.J. Engler, Stiffness gradients mimicking in vivo tissue variation regulate mesenchymal stem cell fate, PLoS One 6 (2011) e15978.

[66] G.C. Reilly, A.J. Engler, Intrinsic extracellular matrix properties regulate stem cell differentiation, J. Biomech. 43 (2010) 55-62.

[67] A.J. Engler, S. Sen, H.L. Sweeney, D.E. Discher, Matrix elasticity directs stem cell lineage specification, Cell 126 (2006) 677-689.

[68] Z. Li, X. Guo, A.F. Palmer, H. Das, J. Guan, High-efficiency matrix modulus-induced cardiac differentiation of human mesenchymal stem cells inside a thermosensitive hydrogel, Acta Biomater. 8 (2012) 3586-3595.

[69] E.A. Klein, L. Yin, D. Kothapalli, P. Castagnino, F.J. Byfield, T. Xu, I. Levental, E. Hawthorne, P.A. Janmey, R.K. Assoian, Cell-cycle control by physiological matrix elasticity and in vivo tissue stiffening, Curr. Biol. 19 (2009) 1511-1518.

[70] N.S. Peters, New insights into myocardial arrhythmogenesis: distribution of gapjunctional coupling in normal, ischaemic and hypertrophied human hearts, Clin. Sci. (Lond.) 90 (1996) 447-452.

[71] H.S. Duffy, Cardiac connections-the antiarrhythmic solution? N. Engl. J. Med. 358 (2008) 1397-1398

[72] S. Fernandes, H.V. van Rijen, V. Forest, S. Evain, A.L. Leblond, J. Mérot, F. Charpentier J.M. de Bakker, P. Lemarchand, Cardiac cell therapy: overexpression of connexin43 in skeletal myoblasts and prevention of ventricular arrhythmias, J. Cell. Mol. Med. 13 (2009) 3703-3712.

[73] G. Hawat, P. Hélie, G. Baroudi, Single intravenous injection of connexin 43 mimetic peptides protect ischemic heart in vivo against myocardial infarction, J. Mol. Cell. Cardiol. 53 (2012) 559-566. 